\title{
"Comparative Constitutional Law and Legal Culture: Asia and the Americas": an overview of the CRNO1 under the Law and Society Washington, 2019 Meeting
}

\author{
Fernanda Duarte ${ }^{1}$ \\ Rafael Mario Iorio Filho ${ }^{2}$ \\ Ronaldo Lucas da Silva ${ }^{3}$
}

The Collaborative Research Network (CRN) is a Law and Society Association's iniciative that seeks to develop cross-disciplinary and cross-national research projects which intend to overcome the disciplinary barriers enabling the growth and integration of the social study of law. Organizing theme sessions for the LSA annual meetings, the CRNs can be a forum in which scholars, professors, students, as well as practitioners who are interested in interdisciplinary studies can organize discussions, share work, exchange ideas and build networks.

The CRN 01 - named Comparative Constitutional Law and Legal Culture: Asia and the Americas - was created in 2015, during the LSA Seattle meeting. It examines legal development, constitutional law and legal cultures from the perspectives of both legal sociology and comparative law regarding Asia and the Americas. In this age of globalization, when economic ties between these regions are gaining strength and momentum, it becomes a necessity to study them comparatively. This is especially important when developing economic relationships bring issues such as the rule of law and protection of human rights to the fore. In particular, it seeks to understand how political and historical paths, as well as global influences such as universalization of human rights and democratic constitutional values, have shaped the formation and evolution of constitutional law and legal culture in

\footnotetext{
${ }^{1}$ Professor of Law, PhD. LSA/CRN01 organizer. PPGD/UNESA and UFF. Brazil.

${ }^{2}$ Professor of Law, PhD. LSA/CRN01 organizer. PPGD/UNESA and UFF. Brazil.

${ }^{3}$ Professor of Law. LSA/CRN01 organizer. UNESA, Brazil.
} 
these regions various countries. It further seeks to examine the manifestations of contemporary legal culture in the political aspects of constitutional law, and in implementing democratic processes and human rights. The CRN brings together scholars engaged in these thematic and regional foci.

The CRN 01 would like to acknowledge the support given the following LSA - Law and Society Association, Estácio de Sá University (UNESA) and Institute of Comparative Studies in Conflict Institutional Management - INCT-InEAC/UFF.

In 2019 CRN 01 took part in the International Meeting on Law and Society, in Washington - DC, USA which took place from May $30^{\text {th }}$ to June $02^{\text {nd }}$. The group activities are showing strength and diversity year by year. This time it has hosted 28 paper sessions plus four roundtables and a business meeting. The following report is exclusively dedicated to the papers that were selected to join the paper sessions according to the meeting program ${ }^{4}$.

\footnotetext{
4 The program can be found here:

https://www.lawandsociety.org/docs/2019ProgramMay10toLSAComplete002.pdf. Accessed Dec 102019. 


\section{Session I:}

\section{Current legal issues in Asia and the Americas: economic and social rights}

\section{Submission Number: 1840}

\section{CRN: 01}

Session Organizer: Fernanda Duarte - UNESA e INCT/InEAC/PROPPI/UFF

Chair: Jairo Lima - University of Sao Paulo

Discussant: Leonardo Cofre - Universidad de Chile

\section{Description:}

This session covers legal and social issues in Asia and the Americas. The focus will be on work related to current trends in these regions. Examples might include discussions of contemporary political or legal challenges faced by governments or social groups, analyses of emerging trends in legal theory as they are related to Asia or the Americas, and/or projects that concentrate on particular legal or social problems endemic to societies in either region. Papers dealing with economic and social rights are welcome.

Primary Keyword: Economic and Social Rights.

Secondary Keyword: Economy, Business and Society.

\section{$\underline{\text { Papers }}$}

A Legal Pluralist Approach to Realizing the Rights and Ensuring Safety of Construction Workers in Cambodia: Regulating Multinational Construction Corporations

Cambodian workers have been often injured and treated unfairly on construction worksites. From a legal perspective, the main problem is not the absence of adequate legislation, 
although many laws could be reformed. Rather, the central problem is ensuring that state and non-state actors, such as the multinational companies that invest and operate the construction worksites in Cambodia comply with legal norms governing labour relations and workplace safety and take concrete steps to address the concerns of the workers. My dissertation considers how the core rights of these workers can be secured by states and non-state actors, applying a legal pluralist approach to regulation. This approach would consider both formal state law as well as range of non-state regulations and standards set and enforced by nongovernmental organizations (NGOs), multi-stakeholder organizations, and industry associations. In so doing, my dissertation assumes that state law is not the only response and considers what combination of legal regimes would provide the most effective legal framework to realize the rights of construction workers. Although this dissertation takes positive (state) law seriously, it applies a range of sociological and political economy perspectives to examine how legal norms work in practice and to critique formal legal institutions and processes. It will explore the views of workers, senior officers in multinational construction corporations, state officials, and NGOs on corporations' approach to labour relations and workplace safety issues. Their views will inform my understanding of how different legal norms and regimes work or fail to work in practice, in order for me to offer a concrete and informed understanding of how a legal pluralist approach to construction workers' rights could be realized.

Presenter: Ratana Ly - University of Victoria

\section{State-Owned Enterprises under ASEAN Regional Competition Policy: Lessons from the} European Competition Network

The present study analyzes the current level of progress in introducing a regional competition law and policy that would create a level playing field for the businesses within the ASEAN Economic Community (AEC). It is specifically focused on the state-owned enterprises (SOEs), which dominate various key industries in the ASEAN countries. The paper explores the ASEAN members' approach towards SOEs in their national competition laws as well as in the ASEAN Regional Guidelines on Competition Policy. The comparative analysis 
demonstrates certain degree of heterogeneity in regulatory approaches towards SOEs among the ASEAN members. It also addresses the functionality of the current "ASEAN way" of coordinating competition law enforcement in cross-border cases, arguing that a differentiated approach may be required in relation to the commercial practices of the SOEs. While several ASEAN states have introduced their national competition legislation very recently, the enforcement practices of other jurisdictions will be informative in shaping regulatory approaches of the ASEAN states. In this respect, the paper will address the experiences from the European Competition Network (ECN) in assessing economic concentrations involving SOEs. A recent string of merger cases involving Chinese SOEs has raised a number of practical problems in applying traditional competition law concepts such as single economic entity, control, etc. in relation to SOEs. The lessons drawn from ECN practice should be instructive for the development of the regional framework for competition law and policy in the AEC and wider Asia-Pacific region.

Presenter: Alexandr Svetlicinii - University of Macau

The Engagement of the Indigenous People in Global Climate Governance: Taking the Community Geothermal Power Plant as An Example in Taiwan

According to the Article 7 of the Paris Agreement, it specifies some important ideas, participatory, transparent, and knowledge of indigenous peoples, which actually presents core values of decision-making process, participation and transparency, and promotes the environmental justice for indigenous people. When involving the indigenous people into the decision-making process, this can be a positive response to the "bottom up" decision-making methodology under the Paris Agreement. Further, from the ideology of deliberative democracy to the new idea of energy democracy, the basic understanding for the good governance would be to emphasize the meaningful participation for the public, both for the majority and minority. Hence, how to connect the issues of climate change and the active role the indigenous people can play, "The Engagement of the Indigenous People in Global Climate Governance" will take the development of the community geothermal power plant in Taiwan as an instance to demonstrate what stage this green energy policy is in, what problems it is 
dealing with, and what the prerequisites it has to meet for the promising achievement. In short, under the existing legal system, the applicable rules for the development of the civilian power installation are actually in shortage. For example, although we have the Hot Spring Act and the Mining Act, none of them can provide a suitable legal structure for the protection of the mineral rights. Also, we do have the Indigenous Peoples Basic Law, proclaiming that the government recognizes indigenous peoples' rights to land and natural resources, but according to the constitutional law, mineral deposits and natural power shall belong to the State. This paper is not trying to define the environmental justice, but would rather to observe what the new policy in Taiwan will do and propose suggestions for bettering the participation of indigenous people under the climate governance for fulfilling the environmental justice.

Presenter: Wen-Hsiang Kung - Soochow University School of Law

\section{Defining the Interdisciplinary Field of ESR Research}

This paper examines the connections between constitutional law, private law, and economic and social rights. Private law defines the entitlements people have, often to the goods that are the subject of constitutional economic and social rights from transactions, include contractual arrangements and property transfers in the market. In many nations, questions about the relation between the constitution, private law, and social and economic rights arose relatively early, before courts had grappled with other questions, particularly about the contours of enforceable social and economic rights on private law. Answering that question requires comparison among institutions - regulation, taxation, modification of private law - and attention to the specifics of politics and institutional designs in individual nations.

Presenter: Mark Tushnet - Harvard University 


\section{The Dark Side of Dignity: Humanization, the Ascent of Corporate Rights, and the Crisis of American Democracy}

This paper seeks to contribute to our understanding of the personification of the corporation by examining the relationship between corporate personhood and normative discourses about the corporation. Socio-legal scholarship since Mark (1987) has approached the question of the personification of the corporation by treating personification as a pragmatic choice informed by a functionalist need of jurists to fit the corporation within the American legal liberal order. Likewise, many scholars have either raised skepticism or defended the discourse of "corporate social responsibility" as a normative basis for mediating the risks, tensions, and threats the corporation poses to American democracy. In this paper I seek to move beyond this impasse by understanding normative discourses of corporate behavior as a rhetorical basis by which corporations have come to be personified and thus gain and exercise legal agency. Drawing on postmodern legal theory, namely Judith Butler and Nietzsche, I will advance a discursive theoretical approach toward analyzing two popular postwar normative discourses - "corporate social responsibility" and "corporate citizenship" - and argue that they have played a critical role in producing a historical and cultural context by which corporations have come to be humanized in critical Supreme Court rulings since the 1970s. Accordingly, normative discourses such as "corporate social responsibility" and "corporate citizenship" can be understood as more than attempts at principled normative constraints; rather, they can be understood as discourses that actually culturally produce public imaginaries that dramatize the corporation in ways that contribute to its personification under the law, and can thus be understood as a basis for legitimizing the expansion of constitutional rights corporations to the extent that such dramatizations actually reconstitute the way corporations are addressed and can ultimately claim to address democratic citizens.

Presenter: Stephen Rahko - Indiana University 


\title{
Session II:
}

\section{Current legal issues in Asia and the Americas}

\author{
Abstract $\mathbf{N}^{\circ}: 1338$ \\ CRN: 01 \\ Session Organizer: Fernanda Duarte - UNESA e INCT/InEAC/PROPPI/UFF \\ Chair: Ronaldo Lucas da Silva - Universidade Estácio de Sá \\ Discussant: Bruno Rezende - UNESA
}

\section{Conclusions:}

This session covers legal and social issues in Asia and the Americas. The focus will be on work related to current trends in these regions. Examples might include discussions of contemporary political or legal challenges faced by governments or social groups, analyses of emerging trends in legal theory as they are related to Asia or the Americas, and/or projects that concentrate on particular legal or social problems endemic to societies in either region.

Primary Keyword: Access to Justice.

Secondary Keyword: Legal Culture, Legal Consciousness, Comparative Legal Cultures.

\section{$\underline{\text { Papers }}$}

\section{Post-humanism: the dignity of animals and free speech in Brazil and in the United States}

Dignity is a concept linked to the human being, however, even among humans, it is argued whether the fetus and the mentally disabled would have the same dignity. Post-humanism proposes to develop a discussion disregarding the anthropocentric view. Recovering the animality of the human being is a movement that requires the revision of the concept of dignity. Giving dignity to animals within the current social biopolitical frame is challenging, but it is undeniable that animal defense movements around the world reflect laws that 
increasingly recognize animal sentience. This work will seek to demonstrate that dignity must come before the law, as Cary Wolfe affirms, and the framework of this guarantee is found in the Brazilian Federal Constitution even restricted to human beings but that must be understood in a systematic interpretation including animals and prohibiting the sale of animal cruelty's videos. The US Supreme Court created exceptions to the First Amendment, but declined to create one for animal cruelty. The paper shows that animal ethics builds a positive responsibility which if based on a public animal defense policy is able to reshape legal structures.

Presenter: Lucia Frota Pestana de Aguiar Silva - Universidade Estácio de Sá

Non-Presenting Co-Author: André Gustavo Corrêa de Andrade - Universidade Estácio de Sá

Free speech in Brazil and in the United States: from animal adoption campaigns to electoral disputes, the new use of social media.

With the strength of the Internet, social movements have acquired new frameworks for society. New and fast relationships between different social actors began to form, including more individuals in this important exercise of citizenship. This new activism has as essential characteristic: the leading role of free speech in social media. The Internet has become the main tool for recent social struggles, since its growth helped to combat without physical contact, the contemporary struggles, changing their places of action, where joint efforts that were previously unfeasible to carry out, since campaigns to protect animals even until electoral campaigns. This new scheme of social relations allowed the demands of groups to overcome local boundaries be heard throughout the world, giving the opportunity for each citizen to be interpreter of their own social struggle, and simultaneously, to integrate networks with common ideals. In this scenario of globalization individual political and civic collaboration can arise in the service of a new concept of greater dignity, including animals and other causes that mobilizes enthusiasts for social progress.

Presenter: Patricy Justino - FGV Projetos 


\section{Animal Rights in Brazil and United States: a criticism of welfarism for the dignity of the animals}

The rise of the animal rights movement emphasizes the current social demand for changing the legal approach to animal protection through abolitionism, a theory that defends an intrinsic value of animals. Although the current Brazilian`s civil law defines animals as properties or things, science has proved that animals are sentient beings, since certain anatomical portions of their nervous system - which may be related to basic human feelings appear in all vertebrates. Consequently, it should not be acceptable for someone to hurt, exploit, or kill another sentient being in order to satisfy their interests. The animal rights movement faces a difficult situation in society, as there is another theory that accepts the use of animals for human interests. This attitude is a consequence of speciesism, the notion that humans are a superior species that can explore other species regardless of their feelings. However, the discussion on animal rights has increased since when the conflict between welfare and abolitionism has intensified. This paper will show how the Brazilian Constitution deals with the legal protection of animals and will argue why welfarism is ineffective.

Presenter: Maria Luisa Wilman Schiller - Universidade Federal do Estado do Rio de Janeiro.

\section{The production of evidence in the brazilian civil procedure and american civil procedure}

The aim of this study present topical notions comparisons of the brazilian and north american procedure systems, their sructure and dynamics, ianalyzing this dialectic process some relevant point in these systems. The procedures of Brazil and US systems have some similarities, despite the predominance of North American have is cammon law and equity, incorporating the culture of analysis of individual cases judged, and in brazilian how is the civil law of predominance origin which worships the legislated text, although we are currently living the meridian of jurispridence. It intended to highlight this work the similarities in the brazilian and american procedures, highlighting in this regard the special features of both 
systems, verifying preliminarily that both start with application for adjudication exploited by initial, the defendant quot, contestation, education probative to the sentence.

Presenter: Carlos Nascimento - Universidade Estácio de Sá

\section{The political discourse of the STF in ADPF 395 (Constitutionality of Coercive Conduct - CPP, article 260). Guardian of the Constitution or the 'popular will'?}

The present text is the result of some partial conclusions of research still in progress that has as main object of investigation the attempt to understand which are and articulate the elements that form the judicial decisions, especially those that are based on constitutional issues and, in particular, in understanding how the representations and justifications of the Brazilian legal field are articulated in the work of the Federal Supreme Court. It was based on a political idea of constitutional jurisdiction, which it conceives to be the field of disputes of the legitimating force of the institutions and the rights of citizenship. In order to do so, the methodology of Semiolinguistic Analysis of the French Political Discourse was used in order to help explain the following problem: in the judgment of ADPF 395 (Constitutionality of Coercive Conduct - CPP, article 260), the Federal Supreme Court acted as Guardian of the Constitution or subjected to pressure exerted by society? The work of the Judiciary in contemporary societies demonstrates some weaknesses that can contribute to conflicts becoming explicit and often not governed by law and the courts. Possible social pressure on the Judiciary's activity may entail a constitutional tension between this Power and the Legislative, indicating the need for investigation on the social functions of the judiciary, especially those that refer to the role of the Judiciary in democratic societies and the limits of their performance. In this sense, the present study, which is the object of a preliminary study, aims at visualizing the Federal Supreme Court's action in ADPF 395 (Constitutionality of Coercive Conduct - CPP, article 260), seeking to understand the political discourses presented by the Ministers in their votes and to ascertain, if these, departed from the Constitution and doctrine, under the justification of attending to the popular will.

Presenter: Berky Pimentel da Silva - Universidade Estácio de Sá 


\section{The figure of the Ombudsman and the Brazilian Democracy.}

The thesis points out the ombudsman system, and improvement of institutes for a better and more effective administrative procedure. If we want to talk about democracy, efficient State, correct and good service, we need, as a necessary premise, an emancipated and participative population. This is the only way to effectively control and improve what is provided. An administrative procedure that observes fundamental rights is a duty, especially with regard to the right of defense and related principles. In this regard, transparency becomes a requirement, since the citizen, as emancipated to the status of owner, has the power and duty to demand it, except when secrecy is necessary or to protect another fundamental right, such as privacy or intimacy, or even in matters of wich disclosure poses a risk to the survival and security of the State. Once established the understanding that what belongs to the state belongs to everyone, the role of protagonism to be exercised by the population becomes natural, who is based on a context of mere mass population that are eligible for public services, for citizens who are masters and writers of their stories, and therefore voters of public policies.

Presenter: Flavia Affonso - Fluminense Federal University; Advocacia-Geral da União. 


\title{
Session III:
}

\section{Criminal Justice in Asia and in the Americas: restorative justice and punishment}

\author{
Abstract No: 1334 \\ CRN: 01 \\ Session Organizer: Fernanda Duarte - UNESA e INCT/InEAC/PROPPI/UFF \\ Chair: Steven Shih-Chun Chien - Stanford Law School \\ Discussant: Maria Rosa Loula - Instituto Brasiliense de Direito Público \\ Conclusions:
}

This session covers legal and social issues in Asia and the Americas, focusing on work related to Criminal Justice in these regions. Examples might include discussions of contemporary political or legal challenges faced by governments or social groups related to punishment, analyses of emerging trends in criminal legal theory as they are related to Asia or the Americas, and/or projects that concentrate on particular legal or social problems endemic to societies in either region regarding crime and punishment. Discussions related to restorative justice are especially welcome.

Primary Keyword: Criminal Justice.

Secondary Keyword: Violence.

\section{$\underline{\text { Papers }}$}

\section{Victim Impact Statements at Corporate Criminal Sentencing}

The existence of corporate criminal liability is controversial, due in part to arguments that retributive punishment is theoretically incoherent when applied to non-human actors. This 
paper proposes that attention to victim narratives at sentencing renders corporate punishment more productive. I argue, first, that due to shared social intuitions about corporations as personified moral actors, the punishment of corporations along with their executives, if otherwise justified, serves an important expressive function. Evidence suggests that many people share moral intuitions about corporate personhood, which allows the justice system to enhance its own legitimacy by vindicating them. Second, I argue that this expressive function will be better served where prosecutors present victim impact evidence at sentencing, allowing for the public to understand the victim's experience of his harm and the aspects of it related to personified corporate identity. Third, I compare white collar enforcement in the Canada with that in the United States, where prosecutors have the option of using deferred prosecution agreements to avoid trial and/or formal sentencing hearings. I conclude that excessive use of DPAs in the United States has obscured the important role of the victim to the expressive function of corporate punishment.

Presenter: Erin Sheley - University of Oklahoma College of Law

\section{Performing Analysis in Sexual Assault Adjudication}

This paper explores the ways in which crime lab analysts perform expertise when they are called to testify during sexual assault trials. Following Pratiksha Baxi's argument that there is no science outside of the law, we demonstrate how the law itself becomes the arbiter of the scientific standards brought into play during sexual assault adjudication. In this setting, analysts embody expertise through their self-presentation, and their scripted and practiced mode of response. They selectively describe some phenomenon with detail and precision, while simultaneously allowing other mechanisms and calculations to remain "black-boxed." The crime lab analysts' approaches are contingent upon their assumptions of the jurors' collective knowledge and cultural disposition towards race, sexual harm, and sexual consent. We argue that the court, therefore, reifies particular notions of biological race, sexual harm, and sexual consent: namely, the fiction that race has a genetic component, and that sexual harm and the withdrawal of the consent always manifest on the body. 
Presenter: Sameena Mulla - Marquette University

Non-Presenting Co-Author: Heather Hlavka - Marquette University

\section{Taming of the Abused: Docile Images, Threatening Victims and Virtual Evidence of Domestic Assault}

The occularcentrism of the courtroom is changing the ways in which justice is seen to be done. Images are especially important to the implementation of the 'victimless prosecution' of domestic violence. Presented as a benevolent intervention protecting victims from the assumed trauma of a criminal trial, the various iterations of this form of evidence collection rely heavily on image capture - particularly of the victim and especially of her injuries. Images of injuries create a 'data double' of the victim, a virtual proxy who is not always as protective of her originator as prevailing logics suggest. The data double plays the role of docile, curated victim, rife with vulnerability and an uncanny ability to embody the fragility of victimhood written into scripts of domestic violence. The data double embodies the perfect victim in the sense that she is always and forever in temporal proximity to the assault. Her bruises do not heal, she cannot access time nor reflection and most importantly, because she has no future self, she can never change her story. Fixed in image, she is a battered woman in perpetuity. The flesh and blood victim, in contrast, can and does move on, she heals, she changes and in so doing, she threatens the very processes meant to 'protect' her, hence the need to quiet the flesh in order that the virtual might speak instead. I interrogate the relationship between these two characters, theorizing that the images turned victim do violence to the flesh and blood victim by condemning her will (Ahmed, 2001), emotions (Walklate, 2014), and animation. I argue the victim made of pure virtuality is simultaneously tamed in the court while weaponized against her originator. Drawing on an in-depth case study of State of West Virginia v. Peter Lizon, I show how the data double is made to accuse her originator of egregious digressions from the script of assault. It is the flesh victim who ultimately stands accused of betraying and victimizing herself.

Presenter: Dawn Moore - Carleton University 


\section{Legal Mobilization Among Incarcerated Fathers: Experiences in County Jail}

Research on legal consciousness and legal mobilization helps establish the range of motives for legal action amongst lay people (Ewick \& Silbey, 1998), but has largely ignored the experience of incarcerated fathers, whose experiences present a unique opportunity to examine rights-talk and disputing for a variety of reasons. Incarcerated fathers, by definition, are embedded in the penal system, and additionally, their incarceration often engenders and co-occurs with other family conflict that can be dealt with in legal ways, such as divorce and child custody (Roy \& Dyson, 2005). Despite the saturation of legal conflict in the lives of incarcerated fathers, there is little information on how these men and their families engage with various aspects of the law, which has the potential to shape many outcomes in their future. I use transcripts from interviews with incarcerated fathers at three Southern California county jails to examine the relationship between construction of legality and decisions to mobilize the law to handle family conflict that arises during incarceration. I hypothesize that incarcerated fathers and their families construct notions of the law contingent upon cultural norms and values, experiences with punishment, and prior family conflict. I contribute to the theoretical literature on conflict and disputing, particularly in hierarchical environments such as carceral settings, and provide insight into how family conflicts are constructed in legal terms for families facing paternal incarceration.

Presenter: Emma Connner - UC Irvine

Dilemmas of the Justice System in the Administration of Conflicts Under Law 11.340/2006 - Case Study

Brasilian Law 11.340/2006 completed 12 years of existence in August/2018. It's considered a landmark in the defense of women's rights and, according to the United Nations, is the third best and most advanced legislation in the world in the face of domestic and family violence against women. However, Judicial Surveys of the Conselho Nacional de Justiça (CNJ) show that the rigor of criminal law and institutional actions have not been able to reduce the number of court lawsuits, which implies recognizing, in principle, the non-reduction of the gender 
index of violence. Many are the adversities experienced by all those involved in the conflict management of the Maria da Penha Law. The present research aimed to "look" at the field of administration of family criminal conflicts through Restorative Justice, trying to face the controversies, dilemmas and possibilities that surround the scope of this Justice System. The Comarcas of Belo Horizonte and Nova Lima, both in the State of Minas Gerais - Brazil, were adopted as a spatial cut. Therefore, it was necessary to direct attention beyond the normativity of Criminal Law. In this context, the development of this work has as a guiding element the Brazilian legal culture, in order to better understand the practice in the field of the aforementioned Law. This topic has been discussed in the NEDCPD group, maintained by the Postgraduate Course in Law at the Estácio de Sá University, in Rio de Janeiro - Brazil, and is in line with the CRN-01 proposal. KEYWORDS: Conflict Management, Criminal Justice System.

Presenter: Ana Paula Faria Felipe - Universidade Estácio de Sá (UNESA) - RJ

\section{Assessing The Predictors Of Transitional Justice Efforts In A U.S. Southern State}

Recent decades have witnessed a global proliferation in practices, policies, and studies surrounding transitional justice. Notably absent from the transitional justice literature however, is a discussion of its relevancy within the United States, particularly as it relates to the centuries of oppression that Black individuals have had to endure. Further substantiating the need for empirical research that examines the impact of transitional justice in the context of the U.S., traumatic pasts are an increasingly prominent topic across the nation in recent years, and this renewed attention has been accompanied by an increase in the number of efforts aimed at addressing anti-Black histories in America as well. Albeit the disavowal of symbols revering the confederacy has emerged most clearly, other transitional justice mechanisms have begun to increasingly appear as well including the emergence of various truth and reconciliation commissions, apologies, reparations, commemorations, and memorials, among others. Social movement scholars suggest that such efforts may be able to reverse the tendency for racially violent legacies to exacerbate present injustices, but it remains unclear what factors inform the emergence of these transitional justice mechanisms. 
Drawing on the Race Reparative Efforts Database, an original dataset of transitional justice efforts in Louisiana, this study uses regression and spatial data analysis techniques to assess county level factors predicting transitional justice efforts in the state and in doing so also assesses whether these efforts are related to the racially violent histories that seek to provide atonement for.

Presenter: Courtney Echols 


\title{
Session IV:
}

\section{Criminal Justice in Asia and in the Americas}

\author{
Abstract No: 1333 \\ CRN: 01 \\ Session Organizer: Fernanda Duarte - UNESA e INCT/InEAC/PROPPI/UFF \\ Chair: Adriano Pinto - Universidade Estácio de Sá/UNESA \\ Discussant: Steven Shih-Chun Chien - Stanford Law School
}

\section{Conclusions:}

This session covers legal and social issues in Asia and the Americas, focusing on work related to Criminal Justice in these regions. Examples might include discussions of contemporary political or legal challenges faced by governments or social groups related to punishment, analyses of emerging trends in criminal legal theory as they are related to Asia or the Americas, and/or projects that concentrate on particular legal or social problems endemic to societies in either region regarding crime and punishment. Discussions related to International Criminal Justice are welcome as well.

Primary Keyword: Criminal Justice.

Secondary Keyword: Crime and Victimization.

\section{$\underline{\text { Papers }}$}

Prosecutorial Misconduct Can Lead to Both Wrongful Convictions and Then Exonerations: The Darryl Hunt Case

Prosecutorial misconduct (Joy, Peter, 2006) is a significant contributor to wrongful convictions, which can lead to exonerations. Using data from the National Registry of 
Exonerations we examine the role that prosecutorial misconduct plays in exonerations. The National Exoneration Registry and the Innocence Project of New York identify prosecutorial misconduct as the most important set of factors that result in the wrongful convictions of exonerees. This presentation advances our understanding of the role of prosecutorial misconduct in two ways, through a case study, that of Darryl Hunt, and through an empirical examination of the geographic clustering of exoneration cases in jurisdictions where prosecutorial misconduct routinely takes place. Finally, our presentation exposes the ways that race, class and prosecutorial misconduct intersect such that Black defendants (mostly men) and those with fewer financial resources who find themselves the most vulnerable to these ethically problematic practices. Finally, we offer recommendations that would reduce prosecutorial misconduct in the first place and address it when it leads to wrongful conviction, often revealed only through exoneration.

Presenter: Earl Smith - George Mason University

Presenting Co-Author: Angela Hattery - George Mason University

\section{Prison System and Human Rights between Brazil and United States.}

Prison System and Human Rights between Brazil and United States. This research aims to show how the study and practice of human rights between Brazil and the United States is conducted. Demonstrate through experiential perceptions the two models of prison systems between these countries. We speak of human rights, but in reality, what we see in the whole of this research is something that has a much greater complexity than we imagine. In the face of a worldwide sphere, human rights have been acquired at the cost of much pain and blood. Our work will show that "human rights" may vary from the point of view of a global sentiment, both in the rhetoric of those who do them and in practice. We understand that every day, "human rights" grow in the prayers of developed countries, but in reality, this is not the way it all happens. We will speak more in this present reflection on the perception of human rights between Brazil and the United States.

Presenter: José Lemos Filho - Estácio de Sá University Via Corpvs 


\section{Beyond Blackstone - Better Still That Ten Guilty Persons Not Escape: Documenting the Crimes of True Perpetrators in Cases of Wrongful Conviction}

Most innocence scholarship focuses on the causes of wrongful convictions, their consequences for exonerees, and their due process implications. In the 18th century, Sir William Blackstone famously observed that it is "better that ten guilty persons escape than that one innocent suffer" (Blackstone 1765-1769: 358). Nevertheless, wrongful convictions may have important consequences for crime control, as a wrongful conviction often means the real offender remains at liberty. In this paper, we document the crimes committed by true perpetrators after innocent people were arrested and convicted for their crimes. Using a sample of cases in which DNA exonerated the innocent and identified the guilty party, we identified 97 true perpetrators who committed at least 311 additional crimes, including 42 homicide-related and 90 sex offenses. Extrapolating from our findings, we estimate that the wrongful convictions that occur annually may lead to more than 42,000 additional crimes. Our findings suggest that protecting the innocent and pursuing the guilty should not be seen as mutually exclusive goals, and that reforms designed to prevent wrongful convictions should be viewed as simultaneously promoting the goals of both due process and crime control. We discuss several of these policy reforms and the importance of framing wrongful convictions as a public safety issue for public opinion and policymaking.

Presenter: Robert Norris - George Mason University

Non-Presenting Co-Author(s): Jennifer Weintraub - University at Albany

James Acker - University at Albany

Allison Redlich - George Mason University

Catherine Bonventre - Guilford College

Leniency agreements carried out at the federal level as effective mechanisms for investigating and prosecuting corruption in Brazil

The paper intends to address the issue of the Leniency Agreements. The research is guided by the following problem: what is the effectiveness of the leniency agreements? In order to 
answer it, it is proposed that research be cut to analyze the agreements signed at the federal level, mainly by the Ministry of Transparency, Supervision and Controllership of the Union MTFC-CGU, a body with legal competence to conclude of leniency agreements between the Public Administration and legal entities. Besides that, it aims to improve these instruments, either in the formalization of the agreements by the involved organs, or in a legislative innovation. The methodology used consists of qualitative and quantitative research with doctrinal apparatus, scientific articles and related jurisprudence, as well as data collection in specialized sites for proper compilation, deduction and textual explanation. The partial conclusion is that, in order to make leniency agreements more effective, it is necessary to work jointly on the bodies responsible for concluding the agreements, which are currently being fought for more competence and / or power, normative interpretation. The MTFC-CGU, the Public Prosecutor's Office and the Court of Auditors of the Union-TCU must work together to improve agreements and fight corruption.

Presenter: Carlos Rodrigues - Estácio University

\section{The verification of institutional actions in a concrete case: The Brazilian institutionalized view of the traffic infraction of alcoholism related to administrative and criminal spheres.}

In order to regulate and manage the traffic of people, vehicles, goods and animals in the terrestrial environment, the Brazilian Traffic Code was born bringing with it guidelines, rights, obligations, mechanisms of state action towards the individual, as well as, it presents a systematized structure, at all levels of the Federation, specialized in the subject of traffic that dialogues, interferes and has its performance interfered by external entities (and powers). Among the various types of conduct classified as harmful to traffic safety, some of them were legally elevated to criminal reprimand, in addition to administrative, such as the prohibition of driving under the influence of alcohol, which creates repercussions in the administrative sphere, generating a specific action of the traffic organs, as well as, in the criminal sphere, creating an action, with a logic of action and parameters not always congruent to administrative law. It occurs that the parameters used and established by the administrative 
sphere, whether in the establishment of analysis and treatment criteria to verify the legal diversion by a driver, or by the very time of response and operation of the institutions, are in disagreement with the related to the agents of criminal proceedings, including the Judicial Police, the Public Prosecutor's Office and the Judiciary, because of different parameters, as well as for working at a different speed from administrative procedures. This mismatch creates communication gaps between the organs and (powers) in the Brazilian administrative and criminal spheres, which sometimes culminates in different or even antagonistic responses in these spheres, generating even legislative responses to such a situation. The present work aims at analyzing the dialogues between the institutions and powers, on the traffic infraction of alcoholism related to administrative and criminal brazilian spheres.

Presenter: Marcos Fernandes de Souza - Federal University of Rio de Janeiro

\section{The Use of Algorithmic Risk Prediction Tools by Parole Agents}

This paper is part of a larger project that examines the decisions parole agents make during their everyday work routines and how these choices influence the trajectories of individuals on parole after prison. During this presentation, I will address the question: how do agents deploy algorithmic risk prediction tools to aid them in their work and in what ways does this influence the role of agent discretion? The paper draws from approximately 50 interviews with agents in three Midwest counties. I examine the complex ways that discretion manages to still operate in a world where-to an extent-there is an increased effort to limit its use, as well as automate supervision work and reform pre-existing institutional practices. My dissertation will consider whether parole supervision's increased emphasis on control, as well as its use of algorithmic risk prediction tools has implications for prison and jail returns.

Presenter: Chloe Haimson - UW-Madison 


\title{
Session V:
}

\section{Access to Justice in Asia and the Americas II}

\author{
Abstract $\mathbf{N}^{\circ}: \mathbf{1 3 3 2}$ \\ CRN: 01 \\ Session Organizer: Fernanda Duarte - UNESA e INCT/InEAC/PROPPI/UFF \\ Chair: Berky Pimentel da Silva - Universidade Estácio de Sá \\ Discussant: Adriano Pinto - Universidade Estácio de Sá

\section{Conclusions:}

Considering the geographical boundaries of the CRN1, this session covers challenges to access to justice, considered broadly as the access that citizens have to dispute resolution systems including but not limited to courts, but also to civil and administrative processes that might impact on protecting rights. Papers might include discussions on access to justice on its two dimensions: procedural access and also substantive justice. Examples dealing with issues of effective access to justice, ADRs, the efficaciousness of a justice system in meeting the dispute resolution needs of its citizens are welcome.

Primary Keyword: Disputes, Mediation, and Negotiation.

Secondary Keyword: Access to Justice.

\section{$\underline{\text { Papers }}$}

\section{Justice in Arbitration: the consumer perspective}

Current empirical studies on consumer arbitration primarily focus on the outcomes of arbitration proceedings between consumers (and employees) and companies. The studies overwhelmingly emphasize on variables such as repeat players (Bingham 1997 \& 1998; 
Chandrasekher \& Horton 2019), the likelihood of success (Searle Report 2009; Colvin 2011; Calvin \& Gough 2015, CFPB Study 2015), and effective vindication of consumers' statutory rights (Resnik, 2014). These studies disregard the consumer experience and/or consumer perception of the (mandatory) arbitration proceedings (Hollander-Blumoff \& Tyler 2011). To borrow the language from psychology, distributive justice has been the primary focus of these studies while other aspects of justice including procedural, interpersonal and informational justice have not been thoroughly studied. Drawing on novel empirical surveys, this present study analyzes (a) consumers' priorities in resolving their disputes with companies (distributive justice vs. procedural justice, interpersonal justice and informational justice); (b) preferred modes of resolving disputes (in-house, mediation, binding arbitration); (c) consumers' perceptions of alternative dispute; (d) (d) consumers' perceptions of companies which use alternative dispute resolution in spite of other methods. Additionally, and in order to fill a significant gap in the literature, this study analyzes the consumers' backgrounds (e.g. race, sex, etc.).

Presenter: Dr. Farshad Ghodoosi - Morgan State University

Presenting Co-Author: Dr. Monica Sharif - Morgan State University

\section{Meditation in Brazil-Concept and Effectiveness in a Country with a Litigating Culture}

This paper aims to describe the mediation in Brazil as a form of access to Justice through an alternative or adequate way of dispute resolution in a country where the legal culture is traditionally attached to litigation. The new Brazilian Civil Procedure Code (2015) as well as the Brazilian law of mediation (2015) brought significant changes in a scenarium where the Judiciary, through a judge's decision, was the only response available to the parties controversy. The paper also dialogue with CRN1 concerns because it reflects and shows the brazilian legal cultural issues. The country has seen a considered growth in the use of alternative methods of dispute resolution, which is very important in terms of relieving the system, considering that in 2016 over 100 million cases crowded brazilian courts.

Presenter: Cristiane Motta - Universidade Estácio de Sá 


\section{May conciliation and Mediation still be considered an alternative way to solve disputes in Brazil? A brief comparison with the Brazilian System of Conciliation and Mediation and the Common Law countries}

Conciliation and Mediation are concepts that seems to be quite fashionable nowadays in Brazil in the Judicial and Extrajudicial fields. They are considered an efficient and meaningful way to solve conflicts. However, they are still not working properly in this country. These concepts represent the process of institutional changes through which Brazilian society has been passing since the 1980s. In this paper we may compare those ideas to some countries that belong to Common Law tradition, such as the United States of America where justice without Lawyers or Courts are applied in many communities for more than three centuries ago. The Mediation Law is recent in Brazil and was published in 2015, differently from countries like Portugal, Argentina, Canada and the United States, where the same law is much more older. The paper will also make a comment and have a discussion about the Brazilian New Civil Procedure Code, from 2015, that includes conciliation and mediation as a principle and also an obligation in the procedure, if just one part wishes so. To conclude, the primary question that guide the research is how conciliation and mediation, when properly applied, can reduce the gap between the Law, the Courts of society, reestablishing the dialogue and dignity.

Presenter: Giselle Beran Medella D Almeida - Universidade Estácio de Sá

\section{Consumer privacy protection in Brazilian Law}

The onset of the Internet is undoubtedly one of the greatest human achievements. Its usefulness as an unlimited information network and as a means of communication and rapprochement of people represents an advance whose revolutionary dimensions, so immense, are still difficult to evaluate. This incredible technological development, however, also has negative aspects, such as the widening of possibilities for violation of individual freedoms, in particular privacy, a term used here in a broad and generic sense, which is comprehensive of the intimacy and private life of man. The rights to privacy were erected by the Brazilian 
Federal Constitution to the condition of fundamental rights. The Brazilian Consumer Protection Code, in turn, explicitly regulates databases, ensuring consumer protection against undue storage and disclosure of their data, regardless of the existence of a contractual legal relationship. The Consumer Code uses the expression consumer to refer to the person who had his name inserted in a consumer file adopting such protection also to so-called "assimilated consumers", that is, any victim exposed to the practices provided for in the Code. This equalization ensures legal protection even to people who are not considered, at first, direct consumers, even allowing the protection to be extended to those whose data is archived by mistake. Although the rules of the Code of Consumer Protection are pioneering, brazilian legislation lacks a comprehensive protection of privacy and insufficient to protect the user of the Internet against acts that violate their privacy.

Presenter: Vitor Sardas - Universidade Estácio de Sá

\section{Consciousness Objection in Consumer Protection and Gender Equality Rights}

Consumer relations have norms designed to end or, at least, mitigate the natural economic imbalance between supplier and consumer. For this reason, the legislation establishes that refusal to service or sell products is an abusive practice. However, there are situations where the supplier refuses to formalize the consumer relation claiming that, in doing so, he would have his moral, ethical, philosophical and/or religious convictions violated - a possible objection of conscience. We intend to carry out in this article a reflexive analysis on the legitimacy of this claim in Brazilian Law, considering the potential violation of fundamental rights of the alleged consumer, especially in cases where the reasons given for the refusal may be understood as hateful discrimination related to gender diversity. To do so, we will counteract Brazilian and US legal norms, doctrine and jurisprudence and verify that both countries understand that fundamental rights are subject to restriction, since they are not isolated pieces in the legal order and are bound to the maximum value of the dignity of the human person. The methodology adopted contemplates the logical-deductive method, through bibliographical and jurisprudential research on the subject. 
Presenter: Livia de Paula - Universidade Estácio de Sá

Presenting Co-Author(s): Leonardo N. Lopes dos Santos - Universidade Estácio de Sá

\section{Online Courts: The Promise of Accessibility for Litigants without Lawyers}

Online courts hold the promise of making justice more accessible and affordable, as a dispute can be filed at any time, from anywhere, by anyone. This is envisioned as a system that is either lawyer-less or has a minimal role for lawyers and is being rolled out in many common law jurisdictions. One of the assumptions underpinning an online court is, therefore, that lay people can effectively explain a dispute to the court, without legal assistance. This is a presentation of an empirical study being conducted in 2018-2019 that aims to test how lay people explain their claims to court in comparison with lawyers. It draws on two sets of data: (1) a sample of 100 court forms that have been retrieved and analysed, comparing lawyer and self-represented litigant completed forms; (2) laboratory study comparing how lay people and lawyers used a mock version of the Canadian Civil Resolution Tribunal portal to explain a civil dispute. The study considers how effectively litigants explain their disputes to a court and how this differs from the strategies and style used by lawyers. In doing so it considers whether the promise of 'accessible justice' can be realized in a lawyer-less online court, what might be lost, and what strategies that might be needed to support lay people in using such courts.

Presenter: Bridgette Toy-Cronin - University of Otago.

Non-Presenting Co-Author(s): Tatiana Tkacukova - Birmingham City University;

Bridget Irvine - University of Otago. 


\title{
Session VI:
}

\section{Human Rights in Asia and the Americas: immigrants and refugees}

\author{
Abstract No: 1330 \\ CRN: 01 \\ Session Organizer: Fernanda Duarte - UNESA e INCT/InEAC/PROPPI/UFF \\ Chair: Bruno Rezende - UNESA \\ Discussant: Rubens Beçak - Universidade de São Paulo \\ Conclusions:
}

This session covers legal and social issues in Asia and the Americas related to the human rights debate. Examples might include discussions of contemporary political or legal challenges faced by governments, social groups or individuals, analyses of emerging trends in legal theory as they are related to human rights in Asia or the Americas, and/or projects that concentrate on particular legal or social problems related to human rights and endemic to societies in either region. Papers dealing with issues of disabilities, immigration and refuge are particularly encouraged.

Primary Keyword: Human Rights, International Human Rights.

Secondary Keyword: Migration and Refugee Studies.

\section{$\underline{\text { Papers }}$}

\section{Anti-slavery activism and the political narrative of modern slavery}

Anti-slavery advocacy groups often call upon citizens of the Global North to engage in political activism in order to combat modern slavery and help to 'save victims'. These actions 
include forms of clicktivism and slacktivism, traditional acts of political participation such as donating to advocacy groups, signing petitions and lobbying governments, and more targeted acts unique to the problem, such as 'spotting victims' or engaging in political (or ethical) consumerism. These calls to action contribute to the creation of a political narrative by setting the terms for what constitutes heroic behaviour in the modern slavery story. Narratives typically encourage audiences to engage in 'anomalous replotting' (Gerrig 1993), considering how the ending could be changed if things had been done differently. Calls to action allow citizens to act within the narrative, to change the story. This paper analyses the contribution to the narrative of several calls to action of anti-slavery groups in Australia, the United Kingdom, and the United States of America urge individuals to take. I argue that these calls perpetuate a political narrative characterised by ideal victims, foreign villains, and western heroes, discursively limiting the responsibility governments and citizens of the Global North have for addressing the problem of modern slavery. This narrative is underpinned by metanarratives of Western exceptionalism, redemptive capitalism (Bernstein 2016) and antimigration.

Presenter: Erin O'Brien - Queensland University of Technology

\section{The Ineffectiveness of the Normative Application of Human Rights}

The need to deepen the ethical understanding of respect for the valued human being as the basis of an enlarged democracy, which, in our post-socialist and post-moralist era as Lipovetsky (2011) would say, is the mobile of the research carried out. It is proposed to place the human rights speech in the current socio-political context of crisis of the foundations of the founding paradigm and the structuring of society, lacking a paradigmatic change. The issues addressed concern a critical reflection on the reasons for an absence of human rights effectiveness, called by Santos as counter-hegemonic. The interest in reflecting on the ineffectiveness of human rights arises, inasmuch as, although the theoretical foundations of human rights have already become a widely researched subject, this does not mean that it does not deserve other looks, in turn the issues concerning the ineffectiveness of the normative application of human rights are leading to further development. The proposal is 
based on a retrospective of the jusphilosophical and political context in which the notion of "human rights" was born, to point out its fundamentals, , taking into account the contribution of Jusnaturalism and Legal Positivism, in a universe dominated by the rule of law.

Presenter: Edna Raquel Hogemann - UNESA

\section{The International Regulation for Fundamental Rights Protection of Environmental Refugees}

The International Regulation for Fundamental Rights Protection of Environmental Refugees Priscilla de Oliveira Paula, student of Estácio de Sá University LLM Program. Summary: This summary deals with the analysis of the International Regulations intending the protection of fundamental rights of environmental refugees and their effective applicability and effectiveness in addressing the social and economic problems generated by the internal and/or external displacement of these environmental refugees. The present study aims to analyze if the existing legislation is sufficient to provide effective protection to individuals who have been forced to leave their conventional habitat temporarily or permanently due to a serious and intense environmental disturbance, natural or artificially caused, through of human action, which puts at risk the maintenance of their basic needs and quality of life. For the present study, it is initially appropriate to present the concept of Environmental Refugees and the existing controversy regarding the denomination of this concept. Next, it is necessary to analyze the existence or not of a specific international legislation that regulates the subject, and if that legislation is sufficient to ensure the protection of the fundamental rights of the individuals that are in situation of refugees by reason of environmental degradation, be it natural or artificial. Keywords: Environmental Refugees - Fundamental Rights - International Law.

Presenter: Priscilla de Oliveira Paula - Universidade Estácio de Sá 


\section{The New Brazilian Law of Migration: Advances and Challenges to the Culture of Human Rights in Latin America}

In the contemporary world, the issue of migration, although not a new one, brings a series of impacts to States for the very people who participate in these flows, who are often deprived of the exercise of rights and assimilation in the political community of the Receiving State. The present work aims to analyze the advances brought by Law 13445/2017, and the challenges to be faced by its regulation, in order to ensure the effective implementation of the new legal order. The analytical legal literature is scarce and has not paid attention to the present theme, whether as object of theoretical construction or even in practice. It follows that there is a need to investigate the legal protection of migrants in their internal aspects. The methodology used was deductive, using bibliographic, documentary and empirical expositions as methods. In Brazil, in particular, the number of immigrants has increased exponentially in the last decades, due to new flows, namely, Haitians, South Americans and Africans. In this context, the migratory phenomenon has brought great opportunities for Brazil to benefit from the cultural diversity brought by migrants and to make efforts to eradicate the legal construction of vulnerability and the exploitation of migrants. The migratory policies in Brazil were based on Law 6815/80 - Statute of the Foreigner, forged during the period of military dictatorship, whose logic was based on national security. With the re-democratization, this regulatory framework was obsolete in the political dimension, and it made difficult the integration of the immigrants and the adoption of public policies that could facilitate their assimilation. In the last decades of the 20th century and in the current decade, the departure of Brazilians to reside abroad and the arrival of migratory flows from diverse origins have made it imperative to replace the legal framework. In 2017, despite the context of great political turbulence in the country, it was promulgated and $\mathrm{p}$

Presenter: Ana Paula Teixeira Delgado - Universidade Estácio de Sá 


\section{Human Dignity and Modern Slavery}

Slavery has existed for thousands of years and still there are many human relations based on a slavery condition. Causes such as population, migration, corruption and discrimination have enabled its alarming resurgence. Two chief peculiarities can be identified: it is cheap and disposable. The global consensus that slavery is unjust is out of question, though labor slavery, sex slavery, forced marriages and child labor enslaves almost 40 million people, as estimated by OIT - International Labor Organization. Rhetoric concerning slavery and enslavement is interconnected with human trafficking. These and other exploitative practices can be labeled as 'modern slavery' although this expression has no great value for International Law. The fight against modern-day slavery requires more then social movements and outrage. The paper aims to answer the following question; Considering that slavery has not been abolished from the world, what make us identify a situation as typically enslaving? And would it be conditioned to a certain conception of dignity? The objective is to analyse the enslaving fact in the light of the idea of dignity conceived in present time. The analysis was based on the theoretical work of Michael Rosen 'Dignity'. The conclusion is that dignity is a wide conception of human condition; it is not limited by a moral concept of respect or any symbolic means of translating the social and individual affair's correction. The method used was the bibliographical research. The approach was critical e theoretical.

Presenter: Sandra Gambini - Universidade Estácio de Sá.

Presenting Co-Author: Vanessa Aigner - Universidade Estácio de Sá. 


\title{
Session VII:
}

\section{Courts and Judging in Asia and the Americas}

\author{
Abstract No: 1328 \\ CRN: 01 \\ Session Organizer: Fernanda Duarte - UNESA e INCT/InEAC/PROPPI/UFF \\ Chair: Cristina Iorio - Universidade Estácio de Sá \\ Discussant: Fernanda Duarte - UNESA e INCT/InEAC/PROPPI/UFF
}

\section{Conclusions:}

This session broadly covers judicial issues in Asia and the Americas. The focus will be on work related to courts, judges and judging in these areas. Examples might include discussions of the political role of judging; challenges faced by judges in relation to judicial independence, democracy, governments or social groups; judicial impartiality; judicial behavior; the psychological aspect of judicial decision making amongst others. Papers dealing with current empirical researches conducted in these regions are particularly encouraged.

Primary Keyword: Judges and Judging.

Secondary Keyword: Legal Culture, Legal Consciousness, Comparative Legal Cultures.

\section{Papers}

\section{The Influence of Immunity on the Behavior and Dignity of Judges.}

Does judicial immunity affect the behavior and dignity of judges? Judges are immune from civil and criminal liability for their judicial acts. Judicial immunity is justified by the need to 
maintain complete independence and discretion of the judiciary. It applies when judges act in excess of jurisdiction, and in some countries even when they act maliciously or corruptly. The only exception to absolute immunity is when judges act without jurisdiction over the subject matter. The Israeli Supreme Court recently decided to embrace absolute immunity and strike off a lawsuit of a refugee, who was unlawfully incarcerated. The Court quoted from two books I published on Immunity, and ruled that the plaintiff cannot sue the State or the judge for damages. My presentation, based on comparative analysis of many cases, aims to determine if immunity affects the dignity and behavior of judges. It demonstrates that most judges maintain their dignity and ethical code of behavior, but sometimes do not hesitate to act maliciously or corruptly. Therefore, in order to protect the dignity of the judicial profession, immunity should not be applied where judges act without jurisdiction or with malicious incentives.

Presenter: Dr Daphna Avnieli - Tel-Aviv University

\section{Seniors on the Stand: Old Age and Judges' Assessments of Witnesses}

This study empirically examines judges' assessments of witnesses in civil judgments $(\mathrm{N}=898)$. When credibility decisions were analyzed with statistical tools, logistic regressions found age and judges' assessments of credibility to be positively correlated. Witnesses who were aged over 60 were three times more likely to have a positive assessment of credibility than witnesses aged under 60. These results stand in stark contrast with trial simulation research, where mock jurors consistently find older adults to be more honest, but less reliable than their younger counterparts. In taking into account the different decision maker, and the complex legal and factual framework within which witnesses are assessed in trials; this study provides new insights not only into who judges believe in their courtrooms, but on the limits of extending jury simulation research to actual trials.

Presenter: Helene Love - Simon Fraser University 


\section{Thin Cases and Limited Warrant: The Standard for Admitting Expert Testimony on Specific Causation}

In order to prevail in a toxic tort case in the United States, plaintiff must employ experts to make two causal assertions: general causation (a substance can cause harm to some people) and specific causation (the substance caused the plaintiff's harm). Commonly, experts attempt to prove specific causation by making a differential diagnosis designed to exclude competing causes as the source of the plaintiff's injury. In federal courts, before the expert will be allowed to testify she must pass a Daubert reliability challenge to the admissibility of the expert opinion. Because federal judges routinely write opinions justifying their decision whether to admit an expert's testimony, these admissibility decisions provide a window into the causal standard they employ in making this determination. Most courts exclude an expert's differential diagnosis evidence when the expert cannot reasonably exclude competing causes (including unknown causes) that singly or collectively offer a more likely cause of the plaintiff's injury. When the specific causation evidence is particularly weak, however, there are numerous cases that adopt what seems to be a lower threshold for admissibility. This paper explores this set of opinions as a window into ways in which the judiciary may rhetorically manipulate the level of justification required for an expert specific causation opinion. It discusses some variables that help to explain the "limited warrant" cases by comparing them to cases where the court requires a better justification before admitting the plaintiff's expert testimony.

Presenter: Joseph Sanders - University of Houston

Non-Presenting Co-Author(s): David Faigman - Hastings College of Law

Philip Dawid - Cambridge University

Peter Imrey - Cleveland Clinic

\section{Order On The Court: John Roberts And The Struggle For Dignity}

The United States Supreme Court is locked in concurrent internal and external struggles for dignity. Public rancor over the recent confirmation of Brett Kavanaugh marked the latest 
chapter in the ongoing descent of the Court's reputation. With the departure of Anthony Kennedy, the Court's lone "swing vote," many commentators predict that the Court -- already widely seen as a politically partisan body that too often renders intellectually dishonest results-oriented decisions -- will become more politicized than ever. At the center of this whirlpool sits Chief Justice John Roberts, a man preoccupied with dignity. Since his high school years, Roberts has worked strenuously to pursue and attain a dignified reputation for himself, cultivating his image as a man above politically partisan infighting and tawdry backroom socializing . Having read biographies about all of his predecessors as Chief Justice of the Supreme Court, Roberts has deemed most of them to be failures, falling into traps of political partisanship and unable to gain consensus among the justices in rendering opinions. Highly aware of his own reputation, and the reputation of his Court, Roberts aspires to establish the Court as a non-political body of jurists beyond rebuke who reach consensus on the most difficult judicial issues -- even as today's Court seems to be drifting in the opposite direction. This paper discusses the role of Chief Justice Roberts on this Court at a crossroads. By reviewing his background, including the jurists whom he admires most and the strategies that he has employed to achieve high levels of success, a picture emerges of the type of legacy that Roberts wishes to leave upon the Court. From this, the paper provides reasonable inferences about what how this desire for internal stability and a public perception of dignity on the Court could impact Roberts's jurisprudence -- and, by extension, the jurisprudential direction of the Court overall -- in the upcoming years.

Presenter: Benjamin Pomerance - New York State Division of Veterans' Affairs.

\section{Judicial Activism, Democracy and Reform in Islamic Law}

There are currently 18 non-Muslim majority countries in the world that formally integrate shari'a (in respect to family matters) into their legal systems. Of these 18 countries, four are considered liberal democracies: Israel, India, Greece, and Ghana-which have long traditions of implementing shari'a within democratic and largely secular legal and political systems. The proposed paper studies these four cases to examine alleged (in)compatibility of shari'a with democracy by specifically looking at what aspects of shari'a these four governments have 
targeted for reform; how they have carried it out, and what challenges they have encountered in the process? Relying upon primary data collected by the author through field research in Israel, India, Greece, and Ghana, the paper argues that the success in reforming Islamic family laws in non-Muslim majority democracies has been closely associated with the ability and willingness of civil judiciaries to take an activist stand on Islamic law. Non-Muslim regimes have refrained from directly interfering with shari'a through executive or legislative means. Rather, they have empowered their judiciaries to introduce necessary reforms in Muslim laws in a piecemeal fashion through judicial lawmaking. However, civil courts-often staffed by non-Muslim judges-could not bring about direct changes in Muslim law. Instead, they have had an indirect effect by pressuring/incentivizing Islamic courts/authorities to undertake selfreform.

Presenter: Yuksel Sezgin - Syracuse University

\section{The Authoritarian Foundations of the Rule of Law: Autonomy and Organizational Capacity in the Judicial Systems of Mexico and Spain}

It is well-established in the research literature that authoritarianism leaves behind cultural and institutional legacies that make it difficult for countries to develop robust democratic regimes and the rule of law. This insight, however, cannot explain why some countries that experienced authoritarian regimes are more successful than others in building strong and effective judicial systems in the post-authoritarian stage. I answer this question by studying Mexico (1934-2008) and Spain (1939-1978) in comparative-historical perspective. Franco's military dictatorship in Spain was a harsher form of authoritarianism than Mexico's PRIregime, with Franco exercising a degree of control over the judiciary unlike anything the PRI ever achieved. As a result, one would expect Spain's path toward the rule of law to have been more troubled than Mexico's. And yet, the exact opposite is true. While Mexico struggles to build a minimally effective judicial system, in Spain the judicial protection of civil and political rights is practically indistinguishable from older, more established democracies. Why? Using extensive archival data collected at various archives in Spain and Mexico, I argue that the key to answering this question lies in understanding the specific mechanisms 
through which the executive power in each country controlled courts and judges during the authoritarian period. This research makes contributions to our understanding of how the rule of law emerges or fails to emerge in post-authoritarian regimes.

Presenter: Michel Estefan - University of California, Berkeley 


\title{
Session VIII:
}

\section{Access to Justice in Asia and the Americas}

\author{
Abstract No: 1327 \\ CRN: 01 \\ Session Organizer: Fernanda Duarte - UNESA e INCT/InEAC/PROPPI/UFF \\ Chair: Cesar Augusto Ribeiro Nunes - Universidade Estácio de Sá \\ Discussant: Rafael Mario Iorio Filho - UNESA, UFF, INCT-InEAC

\section{Description:}

Considering the geographical boundaries of the CRN1, this session covers challenges to access to justice, considered broadly as the access that citizens have to dispute resolution systems including but not limited to courts, but also to civil and administrative processes that might impact on protecting rights. Papers might include discussions on access to justice on its two dimensions: procedural access and also substantive justice. Examples dealing to courts and the efficaciousness of a justice system in meeting the dispute resolution needs of its citizens are welcome.

Primary Keyword: Civil Justice, Adjudication and Dispute Resolution.

Secondary Keyword: Access to Justice.

\section{$\underline{\text { Papers }}$}

\section{A Brief Analysis of Access to Justice Brazilian Federal Small Courts and the Culture of} Litigation Through the Perspective of the Clerks.

Presenter: Cristina Iorio, Universidade Estácio de Sá. 
Access to Justice Integrates Minimum Conditions For a Dignified Existence.

Presenter: Elaine Oliveira, Universidade Estácio de Sá.

How Brazilian Law Tries to Overcome the Economic Barrier in Access to Justice Presenter: Carolina Freitas, Universidade Estácio de Sá.

Co-Presenter: Bruno Rezende, UNESA.

Isreli Law Firms and Pro Bono Representation of Asylum Seekers: Transforming a Political Controversy Into a Humanitarian Cause

Presenter: Neta Ziv, Tel Aviv University.

Supreme Court or Supreme Rapporteus?

Presenter: Marcio da Costa Mello, Universidade Estácio de Sá.

The Indignities of Civil Litigation

Presenter: Mattew Shapiro, Maurice A. Deane School of Law at Hofstra University 


\section{Session IX:}

\section{Human Rights in Asia and the Americas: gender and sexuality}

\section{Submission Number: 1325}

\section{CRN: 01}

Session Organizer: Fernanda Duarte - UNESA e INCT/InEAC/PROPPI/UFF

Chair: Lucia Frota Pestana de Aguiar Silva - Universidade Estácio de Sá

Discussant: Vera Lúcia Raposo - University of Macao

\section{Description:}

This session covers legal and social issues in Asia and the Americas related to the human rights debate. Examples might include discussions of contemporary political or legal challenges faced by governments, social groups or individuals, analyses of emerging trends in legal theory as they are related to human rights in Asia or the Americas, and/or projects that concentrate on particular legal or social problems related to human rights and endemic to societies in either region. Papers dealing with issues of sexual orientation, family models, child's protection and gender are particularly encouraged.

Primary Keyword: Gender and Sexuality.

Secondary Keyword: Human Rights, International Human Rights.

\section{$\underline{\text { Papers }}$}

\section{Plus One: Self-Identification of Significant Others}

Traditionally, event invitations were addressed to 'invitee and wife (or husband)'. Nowadays, invitations are often addressed to 'invitee plus one', allowing the invitee to decide with whom to share it. This paper proposes that the law should adopt a similar approach. Various legal 
benefits are given to spouses, in visas, tax, inheritance, adoption, etc. Historically, limiting such benefits to marital spouses usually identified actual meaningful relationships. However modern family and relationship structures are much more complex. In the modern 'chaos of love', it is very likely that a legally single person would actually have a committed relationship with a significant other. It is possible to be married to one person but actually committed to another. It is further common to have significant, stable and meaningful relationships that are not based on sexual relations but on deep comradery or affinity. This paper argues that granting benefits for the preservation of marriage (and marriage-like relationships), is no longer justified in a world where marriage is - to a large extent - no longer a 'special' all-encompassing relationship as it once was (though in some cases it might actually be). If on the other hand the goal is preservation of actual relationships and family structures, than there is no real reason for preferring marriage - or indeed any sexual relationship - over other, potentially equally meaningful, relationships. The paper therefore suggests allowing se

Presenter: Sharon Shakargy - Hebrew University of Jerusalem.

\section{(Stereo)typical roles - a feminist perspective on the role of law in eradication of harmful gender stereotypes}

The Commission on the Status of Women stated that addressing gender stereotypes 'must be a key element in all efforts to achieve the realization of women's human rights' (2010). Legal scholarship reaffirms this position, considering stereotyping to be one of the biggest challenges for realisation of human rights in contemporary society. Gender stereotypes are thus seen to hinder human dignity because they limit individuals' ability to express their own agency. For this reason, leading human rights organisations (e.g. United Nations, Organization of American States, Council of Europe, African Union) have introduced instruments aimed at the elimination of gender stereotypes. Nevertheless, the topic remains largely under-researched. Drawing on feminist legal theory, this paper addresses the following question: can and should law be used to fight gender stereotyping? Law is considered to be 'neutral' however it is not a value free. It assumes a specific gender order based on deeply- 
rooted norms. Feminist legal theory suggests that law is made by people in power and therefore reproduces existing (patriarchal) structures. Human rights are no exception. Focus on "protection" reproduces hegemonic structures and stereotypes, e.g. women's position as victims. This paper explores the complexity of this topic, with focus on the opportunities and constrains of using law to affect substantive change. The research takes up interdisciplinary approach of law and politics.

Presenter: Olga Frańczak - Univeristy of Surrey.

\section{Troubling the Continued Criminalization of Polygamy in Canada: Considering Twenty- first Century Families and Friendship in the Context of a Politics of Love}

Historically, under the Common Law, families were legal entities while friendships were not. However, in Canada, legal recognition of changing family forms, specifically through samesex marriage and "three parent" cases, both through genetic means and legal parentage, are blurring the boundaries between family and friendship. A growing number of Canadians report living in polyamorous unions. As of 2015, "friendship contracts" are legally enforceable in the Netherlands. In the context of shifting family forms and social attitudes towards definitions of family, the traditional binary opposition between friendship and family status is problematic, rendering continued criminalization of polygamy anomalous and contradictory. This presentation will critically engage Canada's criminalization of polygamy considering shifting attitudes and social research about polyamory. It will problematize the approach taken in the verdict rendered in R. v. Blackmore, 2017 BCSC 192, where a Canadian Court rendered our country's first polygamy convictions under s. 293 of the Criminal Code in over a century.

Presenter: Rebecca Bromwich - Carleton University. 


\section{Sex, gender, and women's legal history}

We live in an era when the meanings of the words 'sex', 'gender', and even 'woman' are increasingly contested. This presents problems not only for those trying to work with the categories of law but also for simple comprehension, let alone finding common ground. Part of the problem lies in the neo-liberal discourse of rights and choice (with gender identity being claimed as a right) and part, I would argue, from ignorance and rejection of women's history. Feminist and other radical histories have always suffered from prompt backlash and attempts at suppression, but it still comes as a shock to older scholars like myself that the battles we thought women had won and the principles we imagined were now embedded and mainstreamed in our laws are in such danger of being dismantled. At the same time as feminist legal history is enjoying unprecedented popularity, how can we move away from, on the one hand, the romanticised notion of traditional women's legal history - of past injustices overcome, and current equality won, by brave heroines and benevolent legal men - and, on the other, the linguistic shift that denies women's separate experience, to tell the story of women's legal history in terms that the next generation can understand, relate to, and learn from?

Presenter: Rosemary Auchmuty - University of Reading

\section{Judicial Activism, Democracy and Reform in Islamic Law}

There are currently 18 non-Muslim majority countries in the world that formally integrate shari'a (in respect to family matters) into their legal systems. Of these 18 countries, four are considered liberal democracies: Israel, India, Greece, and Ghana-which have long traditions of implementing shari'a within democratic and largely secular legal and political systems. The proposed paper studies these four cases to examine alleged (in)compatibility of shari'a with democracy by specifically looking at what aspects of shari'a these four governments have targeted for reform; how they have carried it out, and what challenges they have encountered in the process? Relying upon primary data collected by the author through field research in Israel, India, Greece, and Ghana, the paper argues that the success in reforming Islamic family 
laws in non-Muslim majority democracies has been closely associated with the ability and willingness of civil judiciaries to take an activist stand on Islamic law. Non-Muslim regimes have refrained from directly interfering with shari'a through executive or legislative means. Rather, they have empowered their judiciaries to introduce necessary reforms in Muslim laws in a piecemeal fashion through judicial lawmaking. However, civil courts-often staffed by non-Muslim judges-could not bring about direct changes in Muslim law. Instead, they have had an indirect effect by pressuring/incentivizing Islamic courts/authorities to undertake selfreform.

Presenter: Yuksel Sezgin - Syracuse University

\section{The Right to Reproduction Through Surrogate Gestation in a Compared Perspective Between Brazil and the United States of America}

Reproduction is inherent to the human being, both for the perpetuation of the species and for the satisfaction of intimate yearnings. The right to family planning guaranteed by the Brazilian constitution, the lack of legislation on assisted human reproduction in the country and the way of acceptance the practice of surrogate gestation in the United States lead to question the extent to which the human right to reproduction is guaranteed in the ordering Brazilian law in comparison with the rules adopted in the United States of America. It is also questioned whether the guarantee to this right reaches minorities, such as infertile couples, homosexual couples and single people. The article aims to investigate the arguments favorable and contrary to the cession of the uterus in a comparative perspective between Brazil and the United States of America. The concept of surrogate gestation is initially defined, followed by an analysis of the legislation that regulates practice in both countries, to identify the legal nature and highlight the areas that deal with the subject in the countries surveyed. The research, still under execution, is developed through a bibliographical and jurisprudential review, in a normative theoretical approach with deductive reasoning.

Presenter: Roberto Resende - Universidade Estácio de Sá.

Non-Presenting Co-Author: Lucas Campos - Faculdade Vale do Cricaré 


\title{
$\underline{\text { Session } X:}$
}

\section{Human Rights in Asia and the Americas: freedom and religion}

\author{
Submission Number: 1324
}

\section{CRN: 01}

Session Organizer: Fernanda Duarte - UNESA e INCT/InEAC/PROPPI/UFF

Chair: Ronaldo Lucas da Silva - Universidade Estácio de Sá

Discussant: Leopoldo Soares - Centro Universitário Estácio de Ribeirão Preto

\section{Description:}

This session covers legal and social issues in Asia and the Americas related to the human rights debate. Examples might include discussions of contemporary political or legal challenges faced by governments, social groups or individuals, analyses of emerging trends in legal theory as they are related to human rights in Asia or the Americas, and/or projects that concentrate on particular legal or social problems related to human rights and endemic to societies in either region. Papers dealing with religious freedom are particularly encouraged.

Primary Keyword: Religion and Law, Religious Studies.

Secondary Keyword: Human Rights, International Human Rights.

\section{$\underline{\text { Papers }}$}

\section{The Religious Freedom Restoration Act at 25: A Quantitative Analysis of the Interpretive Case Law}

The necessity of RFRA remains controversial. Proponents contend that there are threats to religious liberty which must be addressed through enhanced protections to free exercise. Such protections are especially important due to the increasing secularization of society without 
which members of faith communities will be required to choose between upholding religious principles and compromising their beliefs. Opponents contend that RFRA remains less about eliminating widespread restraints upon religious liberty and more of a political statement objecting to secularized society including increased acceptance of the LGBTIQA community. This political statement equates personal offense with religious freedom and attempts to foist religious beliefs upon those in broader society. The paper analyzes 303 federal court opinions addressing RFRA from a procedural standpoint or on the merits from 1994 through 2016. The paper measures RFRA's impact through analysis of four data points. These data points are: (1) the dates of opinions; (2) the identity of the claimants; (3) the subject matter of the claims; and (4) the successful or unsuccessful outcome of claims. Discussion of each data point is preceded by an expected observation and concludes with an analysis of the actual results. The paper concludes RFRA has not been as effective as supporters may have hoped nor as pernicious as critics have contended.

Presenter: Lucien Dhooge - Georgia Institute of Technology

\section{Expanding Conscientious Objector Status}

The United States government rarely requires its citizens to kill-or, to do what they believe is killing. It does so during wartime when a draft is in effect. It does so, rarely, when it requires doctors to perform procedures they deem acts of killing. Even in these rare cases, those who believe it is wrong to kill can claim conscientious objector status and thereby avoid both killing and going to prison for refusing to kill. Prisoners who follow vegan or vegetarian diets for religious reasons are entitled to special meals; this is guaranteed both by the First Amendment's free exercise clause, and by statute-RLUIPA and RFRA. Secular vegan or vegetarian prisoners, on the other hand, have no such guarantee-constitutional or statutory. They cannot refuse to kill. Various scholars have addressed the case of the secular vegan prisoner. Some have argued that veganism is a religion. Others have argued that moral beliefs ought to be accorded the same protection as religious beliefs. Bruce Friedrich argues that some enterprising person should incorporate a Church of Veganism, to ensure First Amendment Protection. This article is the first to propose expanding the understanding of 
conscientious objector status to secular vegan and vegetarian prisoners. While vegans and vegetarians refuse to kill animals, in principle their status is similar to conscientious objectors in wartime-that they would be violating their conscience by engaging in unjust killing. That the object of the killing is an animal and not a person, is not relevant. That the killing is indirect, again, is not relevant. The article argues a way forward.

Presenter: Sam Fox Krauss - The University of Texas at Austin

\section{Religious Nationalism and the Idea of Religious Freedom}

In this article, I argue that Religious Nationalism should be approached as a distinct constitutional category, especially when considered in the context of Nonestablishment of Religion claims. In arguing this, the first part of the article develops and defines-through an analysis American Religious Nationalist thought-an ideal type of Religious Nationalism. I show that Religious Nationalists are able to: 1 . Present themselves as the carriers of the true, pure, nature of the nation state; 2. Accept and use the current political mechanisms of the nation state, including democracy, to advance their agenda. These attributes make for a uniquely challenging relationship-a type of intimate rivalry-with the modern nation state and with liberal constitutionalism. In the second part of the paper, I will turn to the different justifications and rationales of nonestablishment -both in seminal cases and in political and legal scholarship-and apply them to Religious Nationalism. My first focus will be on constitutional rationales that argue that the mingling of church and state creates serious concerns of undermining social stability and alienating citizens. I will argue that although this rationale is not persuasive in the case of religion as a general category, it is more so when applied to religious nationalism. Second, I will look at accounts that argue that nonestablishment is important because it prevents the corruption of religion. Here, I show that the rationale is somewhat plausible when applied to religion as a general category, but makes little sense when applied to religious nationalism.

Presenter: Gilad Abiri - Yale Law School 


\section{The wrongfulness of religious discrimination}

When do limitations on our right to freedom of religion or belief also constitute discrimination against individuals on grounds of conscience? Or else, when do those limitations wrongfully disadvantage individuals in the particular sense that grounds unjustifiable forms of discrimination? This paper will pursue the argument that discrimination on grounds of religion or belief is wrongful whenever it violates our general political right to ethical independence. Examples include state limitations on freedom of religion, including instances of lack of accommodation, whose justification depends on impermissible kinds of reason, such as prejudice against specific religious groups. The paper will also argue that the general right to ethical independence helps us identify the shared normative foundation that underlies both freedom of religion and freedom from religious discrimination. This is an important argument for legal practice because it can explain the interchangeable use of the two rights in case-law from the ECtHR and the CJEU.

Presenter: Ilias Trispiotis - University of Leeds

\section{Protecting religious feelings of people of Bangladesh: A Legal Analysis}

In Bangladesh, under Section 28 of the Digital Security Act, 2018, deliberate publication or expressing of spiteful content online which can potentially hurt the religious sentiments of people, is a crime. Furthermore, under Section 295-A of the Penal Code, 1860 a person would be legally accounted for if found guilty of intentionally offending the religious feelings of citizens of Bangladesh. On 25 December 2017, a blogger named Asaduzzaman Noor was arrested from Hazrat Shahjalal International Airport, Dhaka for allegedly ridiculing the Prophet Muhammad and making degrading comments about the religion Islam and Qur'an on his Facebook. In 2016, after the murder of the secular blogger named Nazimuddin Samad, the Bangladesh Home Minister stated that Bangladesh is a secular state and everyone should be considerate of each other's religious sentiments and should be careful what they are expressing through their writings. It is noted that the right to freedom of expression is a distinct symbol of democracy. Free debates should be permitted for the religious beliefs, 
principles and the practices of religious communities within a tolerant society. The religious sentiments of religious people may be hurt by certain expressions. It is especially vital to provide protection to those groups or individuals whose views are not consistent with the dominant perspectives. It is questioned whether and to what degree the state has the right to enforce limitations on the right of freedom of expression to provide protection to the religious sentiments of devoted citizens. Is it correct for the state to intervene with the intention of protecting the feelings of religious communities from offensive speech under the pretext of protecting the rights of other people? This paper will examine these questions.

Presenter: Md Jahid Hossain Bhuiyan - North-West University

\section{Religious education in brazilian public schools: analysis of the political-juridical process of adoption of the denominational model}

This research intends to understand the political-juridical process of adoption of the denominational religious teaching model in public schools. In order to achieve this goal, the political process of editing the norm that regulated religious teaching of denominational nature in public schools, as well as the process of judicial review of the aforementioned norm by the Supreme Court of Brazil, will be analyzed. The methodology consists of identifying the social, political and legal actors involved in each of the processes, analyzing the conditions of participation, the discourses and the meanings attributed to principles, such as religious freedom and secularism. The theme adopted is of particular relevance given the difficulties of access by citizens, specially minority groups, without political representation in the construction of political decisions within the Executive and Legislative, which are increasingly mobilizing the Judiciary, and in special, the Supreme Court of Brazil for the activity of control of the public policies that emanate from the other powers.

Presenter: Erika Pinto - Universidade Estácio de Sá (UNESA). 


\title{
Session XI:
}

\section{Constitutional theory development in Asia and in the Americas}

\author{
Submission Number: 1301
}

CRN: 01

Session Organizer: Fernanda Duarte - UNESA e INCT/InEAC/PROPPI/UFF

Chair: Flavia Lima - UNICAP

Discussant: Denis De Castro Halis - Faculty of Law/University of Macau

\section{Description:}

Societies in Asia and the Americas may seem to have nothing in common given their particularities; however, many countries in these two regions share similar historical and political experiences (e.g. dictatorships, revolutions, democratic mobilizations, civil rights or human rights problems, corruption etc.) and interact more and more pushed by economic and cultural globalization. Nevertheless, these geographically diverse societies, although very different in their current legal and political cultures, may also share constitutional and democratic values. This session intends to bring together scholars engaged in studying the evolvement of constitutional features, either regarding constitutional law or constitutional theory, related to these regional foci.

Primary Keyword: Constitutional Law and Constitutionalism.

Secondary Keyword: Legal Culture, Legal Consciousness, Comparative Legal Cultures. 


\section{Papers}

\section{Human Dignity Beyond Governmental Race Classification: A Core Value of Democratic Constitutionalism}

Racial discrimination requires a standardized criterion for hierarchy. Given the recent emphasis on identity politics it is time to rethink the role of governments in the activity of classifying people, even for beneficial purposes. How can we use affirmative action or diversity as a tool for scrutinizing our biases and nothing else? How can we achieve the social understanding that "minority" does not equal "otherness"? What are the implications of the recent basic law defining Israel as the nation-state of the Jewish People? Building upon Whitman's findings of how the Nazi regime used the United States racial model for defining Jews (James Q. Whitman, Hitler's American Model: The United States and the Making of Nazi Race Law (2017), this paper will analyze the criteria used in classifying people in racial categories in Panama. Under the Government of the caudillo Arnulfo Arias a new Constitution in 1941 was adopted. Using eugenics and cultural rationalizations, this Constitution banned the immigration of the following 'races": "black race whose native language was not Spanish, the yellow race, and the races original from India, Asia Minor and the North of Africa." This Constitution and its 'race classification', has been associated with Nazism, discrediting governmental attempts of classifying people in Panama. The held belief of linking race classification and Nazism reaffirms that human dignity should be beyond governmental race classification.

Presenter: Miguel Gonzalez Marcos - University of Maryland, School of Public Policy

\section{The United States Legal System: The Jurisprudence of Partisanship with Supreme Court Rulings}

The current state of jurisprudence on legal precedent in the global setting, specifically within United States legal system, the case study for this article, is morphing to a cynical view of the partisanship within the court that judges the "supreme law of the land"-the Supreme Court. Rhetorical analysis of Supreme Court practices are altering from the the view of holistic 
decisions by justices to an assumption of partisan bias, or "politically constructed bounds", that justices are subject to, willingly or unwillingly, due to the nature of the position. Though portrayed as a ruling unaltered by partiality from membership in a partisan body, and instead solely outlined by the Constitution of the United States with a duty of upholding the integrity of the document, a judge's role is not as unquestionable. Due to this, it is evident that political parties heavily influence the rulings and thus, precedents of future, past, and present. We analyze the effects of affiliations with a political party on a bipartisan scale-with the common agglomerations of Supreme Court rulings. We also analyzed ruling trends based on a judge's subjective beliefs and deviations each judge makes when ruling on these cases. We have also devised a metric which calculates the probability of a judge deviating from their political party belief and the effects of their belief on their rulings. Future studies will be able to expand on this topic by utilizing the metric as a method of predicting rulings.

Presenter: Pratyush Muthukumar - Cal State LA

\section{The Evolution of Proportionality in Taiwan Constitutional Jurisprudence}

Recent decades have witnessed the migration of the proportionality principle around the world to the extent that it has become the most dominant and powerful interpretive weapon in the judicial arsenal in most countries, and Taiwan is no exception. In fact, Taiwan may be a good case to study proportionality because of three reasons. First, the Taiwan Constitutional Court has exercised the power of judicial review in the past seven decades even during the authoritarian period, and proportionality has been one of the most important tools for the judiciary to either counteract or dialogue with the political branches. Second, notwithstanding that the Constitution in Taiwan arguably expressly stipulates the proportionality principle as a constitutional mandate to protect human rights, legal reception, particularly from both Germany and the United States, is evident in constitutional jurisprudence. Nonetheless, along with the increasing reliance on proportionality, the Constitutional Court's understanding and application of proportionality have changed in the past several years. This involves the third reason: Taiwan Constitutional Court has adapted proportionality to suit local needs and developed its own interpretation of proportionality. 
Presenter: Chien-Chih Lin - Institutum Iurisprudentiae, Academia Sinica.

\section{Dialogue between Courts: an argumentative contribution of judicial decisions?}

The effects of globalization and technological innovations have also been projected on the judicial activity and the jurisprudence of the courts. Between the North American legal system, the Ibero-American and the European there is an increasing interrelation favored by the ICTs, although retaining the legal specificities of each system -mainly those derived between the common law and the continental system-. References to national and international jurisprudence are common, and the precedent doctrine is increasingly studied. The references to jurisprudence both between the European level (State Constitutional Courts, ECHR and CJEU), the Ibero-American sphere (State Constitutional Courts, IACHR) and international tribunals (ICC) - and the American sphere are becoming more frequent, giving rise to the so-called " dialogue between courts ". Therefore, in our work we propose: 1 . Clarify what "dialogue between courts" consists of: as a rule, dialogue is usually spoken when, in the course of a resolution, a review can be found that comes from a different order, that is, different from that in which the resolution goes to deploy its effectiveness. It is clear that there is an exchange of information but the question is whether it goes further, or if there is confusion between what is the existence of a common cultural space and the so-called "dialogue between courts." This dialog will be differentiated from that one called "font dialogue". 2. Analyze if it is an interaction or influence between jurisprudence, that is, if one jurisprudence is influencing others, which would constitute dialogue in the proper sense. It is not about the obligatory respect to the supranational courts (the European courts, for example, with respect to the European Court of Human Rights -TEDH-, the Ibero-American courts, with regard to the IACHR, etc.). This interaction can occur both in a horizontal sense (influence between jurisprudence of different States) and in a vertical ascendin

Presenter: Adriano Pinto - Universidade Estácio de Sá

Non-Presenting Co-Author: Nuria Martín - Universidad de Burgos 


\section{The interpretative fury of Brazilian Supreme Court and the(unavoidable) approximation to "Common Law" System}

Although the fact of existance of Constitucional Clause being independent and harmonic between the State Powers; which are based on Montesquieu work, the Brazilian Supreme Court has been navigating in the lack of the Political System Representative. Moreover, they been moving forward to take other Stative functions and it usually happens in an activist way. Brazilian Constitucion and Law are not flexible; they do offer to the interpreter possibility of changing, The Supreme Courts trying to rebuild them. Brazilian Supreme Court is taking advantage of Executive and Legislative Powers, that seem not to be enacting properly. Futhermore, Supreme Court advances and assumes the responsibility of deciding those laws though judicial decision, which has got " erga omnes" efficiency. There are some examples, such as: The new cause of excluding illicitness of abortion until the third month of pregnancy, the same-sex marriage recognition, an the possibility to apply the punishment when the prossecuted still has resources. That situation closes Brazilian System to Common Law System to Leading Cases. It might seems to be a proper justification to approximate Brazilian System to " Common Law" one and the countries that adopt them.

Presenter: Ruy Walter de Almeida Junior - Universidade Estácio de Sá

\section{Can the Brazilian federalist crisis be explained by abusive constitutionalism?}

Abusive constitutionalism, a theoretical category framed by David Landau, explains how authoritarian regimes can use constitutional amendments as means to grant legitimacy in order to increase and sustain their political power. The original design of the Brazilian federation brought by the 1988 Constitution was deeply altered by numerous constitutional amendments regarding to revenue distribution, always favoring the central government. Political scientists in Brazil, had showed through empirical researches, how that strategy, held by the Union`s Executive branch was favored by the absence of effective means available to States to oppose constitutional amendment proposals. That deficiency in balancing the federative entities participation in the legislative process allowed the central government to, 
through continuous constitutional amendments, weaken States capability to fulfill their constitutional duties, if revenue was concentrated in central government. The main point of this paper is to sustain that a gradual and progressive reduction of the States power in a federalist country, as Brazil, can and should be characterized as abusive constitutionalism. The Brazilian system allows judicial review of constitutional amendments; therefore, the abusive feature can open opportunity to judicial scrutiny - potentially granting States the chance to oppose to such an attack to their own autonomy, which should be fully preserved in a real federalism.

Presenter: Davi Silva - Faculdade Presbiteriana Mackenzie-Rio 


\title{
Session XII:
}

\section{Current legal issues in Asia and the Americas: democracy and dissent}

\author{
Abstract No: 2699 \\ CRN: 01 \\ Session Organizer: Rafael Mario Iorio Filho - Universidade Estácio de Sá e INCT-InEAC \\ Chair: Flavia Lima - UNICAP \\ Discussant: Fernanda Duarte - UNESA e INCT/InEAC/PROPPI/UFF \\ Conclusions:
}

This session covers legal and social issues in Asia and the Americas. The focus will be on work related to current trends in these regions. Examples might include discussions of contemporary political or legal challenges faced by governments or social groups, analyses of emerging trends in legal theory as they are related to Asia or the Americas, and/or projects that concentrate on particular legal or social problems endemic to societies in either region. Papers dealing with democracy, dissent and authoritarianism are welcome.

Primary Keyword: Democracy, Governance and State Theory, Transitions to Democracy and Revolutions.

Secondary Keyword: Authoritarianism.

\section{$\underline{\text { Papers }}$}

\section{Popular Sovereignty and Constitutional Democracy: The Case of Brazil Constitutional Amendments}

Constitutional democracy conduces to the paradoxical admission of a popular sovereignty that must be absolute (to substantiate the validity of the Constitution) and, at the same time, 
limited (to respect the validity of the Constitution). The idea that the people keep its sovereignty after the constituent moment is quite controversial once they are limited to respect the Constitution. However, constitutional democracy can integrate the force of popular sovereignty by means of the openness to constitutional amendments, which depends to a participatory and inclusive process and to a low (or absent) level of unamendability. In the light of this theoretical debate, we propose a discussion over the Brazilian constitutional amendments practice in the 30 years of the National Constitution.

Presenter: Jairo Lima - University of Sao Paulo

Presenting Co-Author: Rubens Beçak - University of Sao Paulo

\section{Dissent in Times of Polarization}

The paper presents an investigation about dissent - how it manifests itself and how it is received - from a legal, philosophical and sociological perspective. It develops the argument that certain types and forms of dissent can interrupt processes of conformist or passive social behavior, which may be key contributors to injustices or bad decisions. These processes of conformist behavior can be paralleled to those identified, and described, by Hannah Arendt, which contributed to form her notion of "banality of evil". Grounded in legal scholarship, but with an interdisciplinary approach, the paper shall: create a typology and a concept of dissent; map and offer illustrations of manifestations and reactions to dissent in different jurisdictions; link that typology and the mapping of dissent with the purpose of laying out parallels between realities and regulatory models in selected jurisdictions. The motivation for the investigation comes from first-hand experiences of individual and collective dissents and the way that governments and people reacted to them. I observed these initiatives and following reactions across the world, not least during my time in mainland China, Hong Kong, Macau, and in Brazil. The overall goal is to advance an interdisciplinary field by developing a definition of dissent that becomes the core of several fundamental rights and freedoms. It is hoped that the paper produces new insights that are helpful to solve legal disputes involving the importance, legitimacy and limits of dissent. 
Presenter:Denis De Castro Halis- Faculty of Law/University of Macau

\section{Judicial Review and Divided Politics: The Case of Taiwan}

This paper considers the Taiwanese Constitutional Court (TCC)'s approach to dealing with divided politics. Since 1990, the TCC has been acting actively (sometimes, aggressively) in constitutional disputes. Landmark decisions include a 1990 ruling that ordered the first-term legislature to leave office, as well as a 2000 ruling that invalidated Taiwan's fifth constitutional amendments. Even in disputes dividing politics and society, such as controversies involved in a shooting event occurring one day before the 2004 presidential election, the TCC has never refused to step in, although the TCC tended not to render definite answers to disputes of this sort. The year of 2018 tells a different story. In 2018, basing on procedural grounds or some minor technical issues, the TCC dismissed several petitions arising from high-profile constitutional disputes. Among these disputes, some related to transformative justice reform initiated by the government dominated by the Democratic Progress Party (DPP), which controlled both executive and legislative branches since 2016. These developments illustrate the TCC's strategy of avoiding involvements in political disputes. Comparative constitutional law literature offers many theoretical and empirical explanations for judicial inaction and caution. A deep look into the context of the TCC's recent change, however, suggests that the TCC's inaction is another form of judicial activism. Using Taiwan's case as an example, this paper considers the TCC's strategy of responding divided politics and examines possible explanations for its inaction.

Presenter: Hsiang-Yang Hsieh - Formosa Transnational, Attorneys at Law.

\section{The Enactment of Digital Security Laws in Bangladesh as a means of Silencing Dissent: Retreat from the Rule of Law}

Following Bangladesh's emergence as an independent nation on December 16, 1971, the founding fathers pledged to establish a society based on democratic values, such as respect for 
the rule of law, the fundamental human rights and the dignity and the worth of individuals, as is evident from the third preamble paragraph and Article 11 of the Constitution of Bangladesh. In order to give effect to these pledges, the Constitution guarantees 18 fundamental rights for the enjoyment of the citizens. Since freedom of speech is the lifeblood of a democratic society governed by the rule of law, the founding fathers made this right an integral part of the constitutionally entrenched bill of rights. However, this Article will demonstrate that the ideal of establishing a society based on democratic virtues have drastically been weakened through the enactment of legislation, namely the Information and Communication Technology Act, 2006 (ICTA) and the Digital Security Act, 2018 (DSA), for allegedly preventing cybercrimes. The broad scope of the ICTA, in particular section 57which made publication of "fake, obscene or defaming information in electronic form" punishable with imprisonment for a maximum term of 10 years and with a maximum fine of USD 119269.10- had been used by the current regime to launch an unprecedented crackdown on the fundamental human rights of individuals, particularly the freedom of speech and expression. Consequently, due to repeated concerns raised by various stakeholders about the use of section 57 of the ICTA to suppress voices critical of the regime, section 57 was repealed through the enactment of the DSA. However, notwithstanding the repeal of section 57 , several of its key features have found a place in the DSA and have already begun to be misused by the regime in the same manner for cracking down on dissent. Thus, this Article will put forward recommendations for ensuring that the democratic virtues on which Bangladesh was founded can be promoted.

Presenter: Dr M Ehteshamul Bari - Deakin University

\section{The Secret Constitution: Constitutional transitory norms as political weapons}

In Mexico, constitutional amendments were traditionally used by ruling groups to entrench their policies and interests, so it would be difficult to modify them by the opposition. However, in recent times, the transitory norms- the temporary rules, with a particular subject, made to adapt new norms to the existing system- have been used at the constitutional level to create general rules, that extend over time, despite them being on the transitory section of the 
Supreme Law (which despite not being in the body of the text, are part of it and thus supreme in hierarchy). This has created a secret Constitution that benefits specific interests and groups. The logical structure of transitory norms goes against that of a regular norm: It has a particular object and subject and it obeys a concrete set of circumstances. This means that by virtue of their design, they can last a specific period of time, or follow circumstances which might make it extend through time, but lead it to an imminent end. Transitory norms are then fated to die. My paper will study ways in which long-lasting transitory norms and those anomalous ones, which are in reality general norms in the transitory section, have been used as political weapons and form a secret constitution that has weight upon the constitutional order even if it is not entirely visible within it. For that case, I will use concrete examples, like the transitory norms of the amendment of 2009 which states that the salary of the President is a cap for that of all public servants and the energy amendment of 2013, which made anomalous transitory norms, although I will canvass all the constitutional amendments since 1992.

Presenter: Roberto Mancilla - Movimiento Ciudadano

\section{Is there any relation between citizen participation and populism?}

Populism is a wide-spreading used concept, receiving the status of a "contested concept". However, a broadly accepted definition conceives it as an ideology, which postulates that those who support the populist movement are the real representatives of "the people", whereas those who are in power belong to a "corrupt elite", who acts against the interests of the rest of population. The ideological aspect has been defined as "thin", allowing that very distinctive regimes to fit within the concept such as, for instance, right-wing Central and Eastern European populist movements, and left-wing South American populism. A first possible aspect of the relationship between participation and populism is that the latter is aware of the current participatory gap. It is the same target attacked by "innovative" theories such as participatory and deliberative democracy. So, they have the same opponent, and maybe a similar diagnostic. Nevertheless, solutions seem totally different. A possible second relation is that certain kinds of populism have a distinctive conception of citizen participation. The idea 
of populist constitutionalism helps to understand this issue. Even when populist movements tend to reject constitutional structures, once in power, populist governments tend to instrumentalise constitutions for their own good. "Populist constitutionalism" serves us to understand that ambivalence. As a theory, populist constitutionalism places itself between popular and authoritarian constitutionalism. The degree of closeness of any extreme will depend on the constitutional project pursued by every regime. I argue that a participatory criterion is useful in this definition. For instance, Andean populist constitutionalism emphasises citizen participation as a constitutional value, translated into new participatory mechanisms even against the incumbent government. Conversely, Hungarian populism tends to use constitutional amendment for eroding liberal checks and balances.

Presenter: Leonardo Cofre - Universidad de Chile 


\section{Session XIII:}

\section{Courts and Judging in Asia and the Americas II}

\section{Submission Number: 2024}

\section{CRN: 01}

Session Organizer: Rafael Mario Iorio Filho - Universidade Estácio de Sá e INCT-InEAC

Chair: Ines da Trindade Chaves de Melo - Universidade Estácio de Sá

Discussant: Edna Raquel Hogemann - Universidade Estácio de Sá

\section{Description:}

This session broadly covers judicial issues in Asia and the Americas. The focus will be on work related to courts, judges and judging in these areas. Examples might include discussions of the political role of judging; challenges faced by judges in relation to judicial independence, democracy, governments or social groups; judicial impartiality; judicial behavior; the psychological aspect of judicial decision making amongst others. Papers dealing with the relation between courts and public policies are particularly encouraged.

Primary Keyword: Judges and Judging.

Secondary Keyword: Courts, Trials, Litigation, and Civil Procedure.

\section{$\underline{\text { Papers }}$}

\section{Practices of precariousness: a case study of illegal home construction in Vietnam}

This paper examines how and why ordinary people in Vietnam engage in illegal home construction and the implications of law in their daily survival strategies. Illegal construction 
takes place either in agricultural/non-residential land or in land areas reserved by the state for so-called development projects. As urban transformation in Vietnam has been fraught with mismanagement and rampant corruption between local officials, real estate companies and brokers, low-income citizens hoping to settle down have found themselves falling victim to deceptions and false promises. Through a case study of a self-employed woman who contested local authority's decision to demolish her house within one year after its construction, the paper demonstrates how legal consciousness is driven by a sense of precariousness shaped by one's socially and economically disadvantaged position. While this woman, similar to other low-income people, acted against the law, the way they justified their act and appealed to local authority brings out values of socialist legality and ideology that the Vietnamese state has proclaimed to uphold. This paper views people's resort to illegal behaviour as practices of precariousness and advances existing understanding of legal consciousness in post-socialist, authoritarian Asia.

Presenter: Tu Nguyen - Centre for Governance and Public Policy, Griffith University

\section{The Judicial Intervention in the Controlof Public Polices: A Brief analysis on the Brazilian Context}

Through the overcoming of old paradigms about the force exerted by the State, and the powers constituted with the emergence of Democratic and Social State of Law, the holding and the guarantee of Social Basical Rights came to be not only a promise, but a requirement of cooperation between all the powers consisting of the Republic of Brazil. Before the Power of Judiciary lived in a dark zone where their participation to consist in verification of the requirements of legality of the acts in this public administration. With the Democratic and Social State of Law arises the need for a more complete participation and cooperative approach between the Judiciary and the other Powers of the State as a way of achieving certain standards provided for in the Basical Fundamental Brazilian Law of 1988. With the "constitucionalismo post-Auschwitz" and Constitution as Fundamental Law the founder and hierarchically above the other norms of the legal system, the role of the Judiciary becomes indispensable in security the normative power of the Constitution. So, in countries such as Germany (BverfGE 33, 303) and Portugal (Judg. 396/2011) the Constitutional Courts when 
instigated began to position themselves in the sense that the control of legality is only one track of legal-political activity belonging Court of Law and also the realization of certain Public Policy expressly laid down in the Constitutions. In Brazil, due to the strong influence received by those jurisdictions this Constitutional Court has been expressing in order to guarantee the fundamental social rights and the possibility of its implementation by the Court, itself because of the inertia of other Powers, since it is a obligation under the Constitution as its possible to realize throught the Judg. RE 808.193-AgR.

Presenter: Vinícius Lameiro - University of Lisbon

Presenting Co-Author: Edna Raquel Hogemann - UNESA

\section{Judicial Deference to Administrative Choices Regarding Social Rights Implementation in Brazil}

The Brazilian transformational project brought by the 1988 Constitution is firmly ground in a broad range of human rights, many of them of socioeconomic nature. Judicialization is a wellknown phenomenon, causing frequently deep judicial intrusion on administrative choices. The research question raised in the paper is whether judicial deference to administrative choices in public policies can contribute to grant equality in the effectiveness of socioeconomic rights. The argument pro judicial deference in the Brazilian scenery relies in two distinct considerations. Judicial review without objective criteria can bring subjective appreciation to the ruling, allowing inequality and the subversion of the distributive concerns that inspired the Administration's choice in drafting public policies. Secondly, judicial review departing from a deferential perspective benefits from the institutional capacity that is recognized to the Executive branch, as it should be according to the checks and balances principle. The Brazilian expansion of the judicial review in socioeconomic rights brought the false impression that, as means to respect human dignity, those rights can be properly grant by judges. That misconception contributes to devaluate the political process in which social rights are design in its content and addressees. Even the rights owners are somehow alienated from that political process, as long as they see the definition of rights content as something to be develop in the judicial realm - and not in the public arena. Rescuing the relevance of 
public policies and of a deferential approach to its scrutiny reinforces public deliberation as a key component of a true democracy.

Presenter: Vanice Valle - Universidade Estácio de Sá

\section{Administrative Disciplinary Processa t Brazil: (Non) Adequacy of the Constitutional Principles}

Will be presented remission to the case law in Brazilian courts with the administrative disciplinary process in Brazil, subordinate by the legislation apt directly to the civil servant, remission to the court jurisprudences, verification of controversial aspects between the practice of disciplinary proceedings conduct by administrative authorities and their adequacy of the constitutional principles and the Law n. 9.784, 1999, relatives to the subject, so that if can have, to the ending of the exposition, a vision as should be treated procedurally the disciplinary offences by the Administrative Agencies and its complements.

Presenter: Elbert Heuseler - Estácio de Sá

\section{Courting Conflict? Trust in the Judiciary and Social Conflict}

According to positivity theory, the public's exposure to the American judicial system and the judiciary's unique set of symbols and processes tends to lead individuals to confer on the institution legitimacy and trust through mechanisms often not available to other political actors (Gibson and Caldeira 2009). The present paper focuses on whether this theory operates outside of the American context, arguing that the legitimacy conferred by domestic audiences upon domestic judiciaries will be less variable than the legitimacy reposed in other governing actors. However, moving to a comparative context implicates a number of potentially confounding factors, including the influence of variation across regime-types, legal systems, and issue areas. Are courts inherently unique, as suggested by positivity theory, or does the resiliency of courts vary across different institutional contexts? In order to answer this question, this study leverages survey data from the Afrobarometer to measure levels of public 
trust in executive, legislative, and judicial branches of government to analyze whether institutional legitimacy varies across different governmental actors in the presence of public opposition to government policy. Public discontent with policy is measured using data coded by the Social Conflict Analysis Database, which identifies instances of protests, riots, and strikes. The paper's statistical analyses provide evidence to support the distinctiveness of judiciaries, finding that social conflict negatively impacts public trust in executives and the legislatures, yet exerts no effect on public trust in judiciaries, indicating that courts across regime-types, legal systems, and issue domains stand apart from other governmental actors.

Presenter: Joseph Cox - University of Arizona, School of Government and Public Policy

\section{The role of judges in Brazilian civil proceedings. Limits and possibilities.}

Modern procedural law, breaking with the classical idea of legal positivism, where the Judge represented the idea of "la bouche de la loi" (the mouth of the law), has been supporting the expansion of magistrates' powers, in order to justify a more proactive and expansive position in the interpretation of the Laws and of the Federal Constitution itself (BARROSO, 2005). The concept of judicial activism is precisely the idea that requires magistrates, when interpreting the law, to re-create their original meanings. It is the representation that the judges must "enhance the meaning and scope of the rules, to go beyond the ordinary legislator" (BARROSO, 2005). Passivity and judicial inertia are part of the classical civil procedure model, in which the judge imposes passive behavior, without any other function in the course of the process, otherwise directing it is seen as "a strictly individualistic aspect of the process", where is a sole interest of the parties, a characteristic that "no longer meets the scopes of modern procedural law, which tends to be publicized". CAMPANELLI (2006, pp. 63-64). The purpose of this paper is to try to understand, from an empirical perspective, how the idea of judicial activism has been operationalized in Brazilian judicial practices and rituals. From a bibliographical review associated with formal and informal interviews conducted with Brazilian magistrates, it is intended to make explicit the discourses and representations and meanings that have been attributed to judicial activism in Brazil. "The judges are seeking the best way to do justice, even if they need to go beyond what the law 
says. It is very important that the Judiciary suppresses its inertia [of the Law]. " Discover the "sense of the law. This is the modern function of the judge in the process. " These and other statements were revealed to us by magistrates interviewed during the fieldwork that mobilized the idea of this paper.

Presenter: Daniel Navarro Puerari - Universidade Estácio de Sá

Non-Presenting Co-Author(s): Bárbara Gomes Lupetti Baptista - UVA - UFF

Vanele Falcão - UVA 


\title{
Session XIV:
}

\section{Criminal Justice in Asia and in the Americas II}

\author{
Abstract $\mathbf{N}^{\circ}: \mathbf{2 0 2 0}$ \\ CRN: 01 \\ Session Organizer: Rafael Mario Iorio Filho - Universidade Estácio de Sá e INCT-InEAC \\ Chair: Lucia Frota Pestana de Aguiar Silva - Universidade Estácio de Sá \\ Discussant: Rubens Beçak - Universidade de São Paulo
}

\section{Conclusions:}

This session covers legal and social issues in Asia and the Americas, focusing on work related to Criminal Justice in these regions. Examples might include discussions of contemporary political or legal challenges faced by governments or social groups related to punishment, analyses of emerging trends in criminal legal theory as they are related to Asia or the Americas, and/or projects that concentrate on particular legal or social problems endemic to societies in either region regarding crime and punishment.

Primary Keyword: Criminal Justice.

Secondary Keyword: Violence.

\section{$\underline{\text { Papers }}$}

What's in a Name? International Law and the Pursuit of Fairness in the Labelling of Absent Defendants

The phenomenon of absent defendants is well-known in International Law and has been at the centre of a long-lasting debate about the possibility of allowing trials in absentia, i.e. criminal 
proceedings in the accused's absence. A less investigated aspect of this phenomenon relates to how International Law labels absent defendants (and names the proceedings conducted in their absence), and what this tells us about the pursuit of fairness at international level. In this regard, a thorough study of the terminology used to refer to absent accused would shed light on the approach adopted in International Law to guarantee a fair treatment of these individuals in criminal proceedings. This paper analyses critically the labelling of absent defendants in International Law. To this end, the author examines three aspects: (i) the international linguistic choices for defining absent defendants; (ii) the procedural consequences of these linguistic choices for the regulation of proceedings conducted in absentia; and (iii) the significance of the language used in International Law with respect to the fair treatment of the accused. Ultimately, it is argued that the qualification of absent defendants reflects the way in which criminal justice systems stigmatise the accused's absence and conceive their criminal procedures thereof. In this sense, International Law guarantees fairness using a language that advances a consistent, non-judgemental idea of justice in International Law.

Presenter: Ilaria Zavoli - School of Law, University of Leeds (UK)

\section{The Limitations of the Brazilian Plea Bargaining Agreement as na Instrumento f Efficiency of Constitutional Fundamental Rights}

The study analyzes the need to establish limits for the stipulation of benefits in the Brazilian plea bargaining agreement as a way to make it compatible with the first generation fundamental rights of the accused. Law no. 12.850 / 2013, which defines penal and criminal procedural rules related to the organized crime, provides, in its normative structure, special means of obtaining evidence, among which is the Brazilian plea bargaining. In order to encourage more agreements to increase criminal prosecution, the interpretation of the plea bargain as a procedural legal deal has been used by the Brazilian Courts of Law as grounds for the possibility of being agreed benefits in favor of the accused that are not provided by the Law, which reflects a potential injury to third parties' fundamental rights. The study identifies how the issue has been dealt with in its practical aspect in cases of high visibility, especially 
in those related to the so-called car wash operation ("operação Lava-Jato"), in which practices of granting benefits not provided by law have become common, including the creation of new regimes of sentences execution and institutes never covered by the existing laws in the Brazilian legal order. In the face of these practices, the work deals with its central point: the need to establish limits to the clauses contained in the Brazilian plea bargaining agreements with regard to the benefits stipulated by representatives of state persecution agencies as counterpart and encouragement of the cooperation of the accused in facilitating the collection of evidence relevant to the case. Therefore, the study intends to contribute by proposing to draw more precise and secure contours of hermeneutical compatibilization of the Brazilian plea bargain with the rights of the accused, thus achieving a balance between the legitimate search for greater effectiveness of the criminal procedure and the protection of constitutional fundamental rights.

Presenter: Felipe Drumond Coutinho de Souza - Universidade Estácio de Sá

\section{The Rape Culture as na Obstacle to the Effectiveness of Sexual Rights of Women in Brazil}

The present research is developed in the light of the case of Brazilian supporters who harassed Russian women during the Soccer World Cup of 2018, which provoked international outrage after gaining notoriety through its repercussion in the field of journalism and social media. It is possible to affirm that this act is due to social prejudices against women, through which society seeks to naturalize and minimize the inappropriate sexual behavior of a man against a woman while blaming the victim for the violence suffered, the so-called "rape culture". In Brazil, certain misogynistic behaviors become common and everyday aggressions. Such attitudes go against the legal recognition of sexual rights as universal human rights. The conception of sexual rights consists in the recognition of the free exercise of sexuality, which means that any person must be free from violence and coercion related to sexuality, including its most serious forms (such as rape, abuse or sexual exploitation) and its milder forms (Bullying and sexual harassment, for example). This research aims to analyze the culture of rape as an obstacle to the effectiveness of the sexual rights of women in Brazil, being 
developed through direct data collection in bibliographical, documentary and media sources. In order to achieve this objective, this paper aims to: present an approach to sexual rights based on the conception of human rights; analyze the rape culture from a body and gender perspective in order to demonstrate how it violates the sexual rights of women; and, finally, to present the national and international legal apparatus for the protection of the sexual dignity of women. It was concluded that the society has not followed the legal reforms, being demanded more pedagogical interventions than properly legal ones so that the sexual rights of the women are effected at national level.

Presenter: Sarah Dayanna Lima - Centro Universitário Estácio do Ceará

\section{The hipermodern society in the light of Lipovetsky's thought}

It investigates the relationship between exaggerated consumerism in hypermodern society, in the light of Lipovetsky's thinking, and the reduction of criminal conduct of adolescents and young people who grow up and are born in favelas with efficient public policies, notably the strengthening of education. In order to provide as answer to the problem, it is proposed to reflect on the large prison population, especially in the municipality of Rio de Janeiro, composed of youths who committed crimes against property and engaged in illicit traffic in narcotics in an ephemeral search for self-assertion and acceptance based on the "having" to the detriment of "being". Consumerism, lack of resources, and low education are relevant, not the only causes, for maintaining a significant crime rate in this age group. It is argued that there is a certain consensus that preventive measures have more effects than corrective ones, so with investment in education, the part of the population mentioned, notably with a greater degree of knowledge, consubstantiated in the acquisition of relevant information, more specialization and professionalization, higher level of schooling, certainly the financial availability would be greater to the point of providing acquisition of previously unattainable goods and services. The general objective of the work is to propose the implementation of public education policy, from the identification of the essential core of this fundamental right and based on its legal regime. The methodology used is that of deductive reasoning from classic and contemporary nation sources about this theme. 
Presenter: Márcio Silva - Universidade Estácio de Sá

\section{Alternative Practices and Politics of Care: Women Students' Experiences of Rape Culture and Sexualized Violence on Campus}

This paper examines the experiences, understandings, and responses of women-identified students to rape culture and sexualized violence on Wilfrid Laurier University's Brantford campus. Following an overview of our research study, we examine the diverse ways that women-identified students experience rape culture on campus and come up against multiple 'institutional walls' (Ahmed 2017) in their attempts to navigate both the formal and informal university structures surrounding gendered and sexual violence on campus. In the second part of this chapter, we highlight the different ways that women-identified students and alumni respond to these walls, and to rape culture more broadly, by engaging in alternative practices and politics of care, which are oriented toward cultivating caring relations and collectives that are attentive, responsive, and responsible to the needs of particular others, including one's self. These include individual empowerment strategies that challenge dominant norms of femininity and masculinity and offer pragmatic strategies to women to defend themselves (and one another) against male aggression and violence; women's participation in small group discussions and consciousness-raising practices; and cultivating feminist public spaces on campus, including engaging in on-line and in-person education and advocacy initiatives and providing material and emotional care and support to survivors of violence.

Presenter: Marcia Oliver - Wilfrid Laurier University

Non-Presenting Co-Author(s): Rebecca Godderis - Wilfrid Laurier University

Debra Langan - Wilfrid Laurier University 


\section{Human Rights Violations during the Federal Intervention in Rio de Janeiro: An Analysis of the Repressive Action in Deprived Communities of the State}

The present paper aims to analyze the occurrence of human rights violations in deprived communities of the state of Rio de Janeiro, Brazil, during the undergoing period of federal intervention. This form of State intervention, constitutionally established in the article 34 of the Brazilian Constitution, was evoked with the purpose to suppress a serious compromise in the public order and safety of the aforementioned state, based on the argument that it was necessary to reduce escalating local crime rates. Nevertheless, although the exception measure has been established in order to ensure public safety, it has been proven that it has been a significant increase of violence in the state of Rio de Janeiro, since the implementation of such statute. A possibility to this phenomenon in these mentioned locations is the use of abusive and discriminatory police action to suppress crime. The repressive state action in the state may be materialized in execution of residence violations, excessive use of police power, which may lead to the use of lethal methods of crime containment, according to recent researches. Therefore, this research enlightens how such conducts, aside from being transgressing on fundamental rights constitutionally secured, submit local residents to a routine of fear, insecurity and vulnerability, leading to a State omission in reversing this situation of subcitizenship of the citizens of Rio de Janeiro, under the federal intervention.

Presenter: Renata Rocha- Universidade Federal do Rio de Janeiro 


\section{Session $X V$ : \\ Current Legal Issues in Asia and Americas: Technology and Law}

\section{Submission Number: 1841}

\section{CRN: 01}

Session Organizer: Ronaldo Lucas da Silva - Universidade Estácio de Sá

Chair: Jairo Lima - Universidade de São Paulo

Discussant: Denis De Castro Halis - Faculty of Law / University of Macau

\section{Description:}

This session covers legal and social issues in Asia and the Americas related to the human rights debate. Examples might include discussions of contemporary political or legal challenges faced by governments, social groups or individuals, analyses of emerging trends in legal theory as they are related to human rights in Asia or the Americas, and/or projects that concentrate on particular legal or social problems related to human rights and endemic to societies in either region. Papers dealing with issues of technology and law are particularly encouraged.

Primary Keyword: Technology, Technological Innovation, Robot Law.

Secondary Keyword: Human Rights, International Human Rights.

\section{$\underline{\text { Papers }}$}

\section{Open Access in the Economic Sphere: Understanding China's Development}

This paper is the last piece in a series of articles written from the perspective of contemporary non-Western countries, arguing that it is open access in the economic sphere and the interconnected institutions in the areas of property right protection and contract enforcement, 
financial market, rule of law, and the accumulation of human resources that determine economic and human development. The case of China shows again that the theory of North and his colleagues overemphasizes the role of open access to political organizations or competitive democracy in economic development. While Singapore restricts the role of opposition parties, China strictly prohibits opposition parties. Both countries have developed relatively well. I have also analyzed the cases of India, Japan, and Brazil elsewhere to show that open access to political organizations does not play significant roles in economic development or even human development. These cases, however, are much less obvious in explaining my argument than the cases of Singapore and China. If my argument is correct, there are new ways of defining the roles of government in economic development. This paper has also made some preliminary efforts in discussing the roles of government in economic development. The paper, however, does not deal with questions about political regimes with the rule of one party or a dominant party. The case of China also has implications to the theory of the end of history. Future research can benefit from

Presenter: Guanghua Yu - The University of Hong Kong School of Law

\section{'Digital Dignity' as an Oxymoron? China's Contribution to the Future of the 'Culture and Trade Debate'}

'Digital justice' is a relatively new concept related to the rapid changes in technologies due to digitization. In an age of the big data economy, driven by a rapid pace of innovation in computer sciences, bio- and nanotechnologies and cognitive sciences, new and profound regulatory challenges arise notably from their mutual convergence. Resulting from this innovation are often new products, which drastically redefine the boundaries set by existing laws. Linguistically, this phenomenon is reflected in an increasing number of blends of words, such as notably oxymora, like those of the 'culture industries', 'nutriceuticals', 'cosmeceuticals', or edutainment industries. In this context, concepts like 'raw data', 'artificial intelligence' too have been qualified as oxymora. In view of future trends towards robotics and artificial intelligence, perhaps human dignity too must be considered an oxymoron in a digital environment. As oxymora they share different levels of contradictions, which overall 
challenge the mode of binary thinking deeply rooted in legal reasoning. This problem is known from the 'culture and trade debate', which aims to reconcile the apparently opposite objectives of the liberalization of international trade on the one hand and the protection of the diversity of cultural expressions on the other. In this debate, the dichotomous separation between culture and trade was challenged by the emergence of technologies establishing the cultural industries. This paper thus looks at the case of China, which since its accession to the WTO in 2001 has also participated in the debate both as a defendant in the WTO dispute settlement system but also as an active negotiator of bilateral regional trade agreements. It will briefly compare the different conceptual and cognitive approaches of China, the EU and the US to the debate in light of the ongoing international trade disputes and regulatory challenges arising from an increasing digitization of the global economy

Presenter: Rostam J. Neuwirth - University of Macau, Faculty of Law

\section{“Post-Territorial Technologies:" A Comparative Analysis of Data Transfer Regulations \& Territoriality}

Most scholarship on big data and the law has focused on issues relating to collection, use, and distribution of data, and their effects on individual behavior, privacy, and autonomy, or how they perpetuate certain biases, discrimination, and inequality. However, there has not been much emphasis on the new spatialities created by big data, nor on the relationship to territoriality. Regulations of international transfers of data attempt to exercise territorial sovereignty and jurisdiction over a "post-territorial" technology. Big data flows illustrate and challenge the elasticity of territorial sovereignty in international law, entailing a different way of mapping and theorizing global power and authority. Simultaneously local, national, and global, big data is creating new geographies of private and public power untethered to traditional conceptions of territoriality, yet regulation and policy on big data are still linked to territorial sovereignty and jurisdiction. By comparing the regulatory approaches of the United States, European Union, and China, it emerges that they reflect a dual logic with regard to territoriality and big data, at once moving away from it, while at the same time "reterritorializing" by linking regulations to the location of users, data collectors, or 
infrastructure. However, these approaches neglect the novel spatialities formed by big data which require a new language beyond territoriality. Building on Sassen's sociological theories on digital technology and territory, this new language might be termed "data assemblages."

Presenter: Roxana Vatanparast - University of Turin

\section{The Right to Privacy and New Technologys}

The purpose of this article is to analyze the coexistence of the current technological context with the evolution of new technologies and the constitutional principle of the right to privacy, incorporated into the Brazilian legal system by the Federal Constitution of 1988 and by the Civil Code of 2002. The methodology used was the logical-deductive method, based on bibliographical, documentary research. There is also the analysis of foreign jurisprudence in a comparative perspective. The research sought to know the coexistence of personality rights that protect the privacy and private life of the individual in the scenario of extreme ease of disclosure of any information, as well as extensive data collection, due to the technological advance, as well as analyze the current coexistence between the existence of this fundamental right and the expansion of new technologies. It was also analyzed how these new technologies influence data processing and its relationship with a growing vigilance of society in favor of public safety. With the present research it was possible to conclude that privacy is a right still of importance, mainly under the protection of data, besides being endowed with a collective aspect that justifies its primacy, in certain cases, in relation to the right to public security.

Presenter: Vanessa Almeida - Univerdade Estacio de Sá

Presenting Co-Author: Carolina Braga - Univerdade Estácio de Sá

Non-Presenting Co-Author: Carolina Gouvea - Univerdade Estácio de Sá 


\section{Regulation of Collaborative Economy in Brazil: The Airbnb Case}

From the globalization process, the advancement of technology, especially the internet, has fostered new forms of consumer model across the globe. The latest phenomenon is what experts like Aran Sundararajan called the collaborative economy. Ahead of this, the Airbnb platform emerges. Because it is a contemporary business model, there is no Brazilian legal norm that regulates this phenomenon. Thus, a discussion about legal uncertainty arises, under the prism of tax law and, consequently, the necessity or not to institute a regulation on the subject. The object of analysis of this research will be the collaborative economy in Brazil, especially the services offered by Airbnb. It is hypothesized that the model of collaborative economy is a "crowd-based capitalism". In addition, it is understood that for Airbnb to be taxed, it is necessary to define the nature of the service offered. The theoretical framework of the work is based on the analysis of the phenomenon of the shared economy in parallel to ideas defended by authors like Adrian Vermeule. The hypothetical-deductive criterion will be used as methodology, trying to prove the hypotheses exposed. The spatial analysis of the work will take place in the sphere of the Executive Branch and Legislative Branch at the federal level. The time frame of the work comprises the period that began the discussion about the phenomenon of the shared economy, more specifically the year 2010 until the present time. The present work aims to evaluate the Brazilian regulatory landscape in the development of disruptive technologies from the collaborative economy model. As well as investigating the possible tax incidence on Airbnb, considering the current National Tax System. The specific objective is to analyze (i) the obstacles to the consolidation of regulation on the services provided by Airbnb and (ii) the unfolding of this possible regulation, from the point of view of institutional theory and tax law.

Presenter: Gabriella de Sousa Rodrigues 


\section{Session XVI:}

\section{Human Rights, Dignity and Protection}

\section{Submission Number: 4155}

CRN: 01

Session Organizer: Fernanda Duarte - UNESA e INCT/InEAC/PROPPI/UFF

Chair: Ronaldo Lucas da Silva - Universidade Estácio de Sá

Discussant: Rafael Mario Iorio Filho - Universidade Estácio de Sá e INCT-InEAC

\section{Description:}

This session covers legal and social issues related to the human rights debate. Examples might include discussions of contemporary political or legal challenges faced by governments, social groups or individuals, analyses of emerging trends in legal theory as they are related to human rights, and/or projects that concentrate on particular legal or social problems related to protecting human rights. Papers dealing with dignity, religious minorities and free speech are welcome.

\section{$\underline{\text { Papers }}$}

Constitutional Recognition of the Right to Water: Opportunities and limitations in Brazil, Colombia and Peru

Presenter: Lara Cortes, CMI.

Non-Presenting Co-Author(s): Camila Gianella, Pontificia Universidad Católica del Perú. Centre on Law and social transformation;

Angela Maria Paez, Tennessee State University;

Catalina Vallejo, University of Virginia. 


\section{Corporations, universities and the Social Regulation of Speech}

Presenter: Franciska Coleman, University of Kansas School of Law.

\section{Exploring the Unharnessed Power of 'Dignity' in the Irish Constitution}

Presenter: Sarah Fulham-McQuillan, University College Dublin

\section{Free Speech in the Global South}

Presenter: Stephan Stohler, SUNY, University at Albany.

Co-Presenter: Thomas M Keck, Syracuse University

Non-Presenting Co-Autor: Sandra Botero, Universidad del Rosario

\section{Taking Democracy, Dignity and Rights Seriously}

Presenter: Imer Flores, UNAM. 


\title{
Session XVII:
}

\section{Human Rights in Asia and the Americas: Armed conflicts and International Law}

\author{
Submission Number: 1442 \\ CRN: 01 \\ Session Organizer: Ronaldo Lucas da Silva - Universidade Estácio de Sá \\ Chair: Rafael Mario Iorio Filho - Universidade Estácio de Sá e INCT-InEAC \\ Discussant: David Ritchie - Mercer University

\section{Description:}

This session covers legal and social issues in Asia and the Americas related to the human rights debate. Examples might include discussions of contemporary political or legal challenges faced by governments, social groups or individuals, analyses of emerging trends in legal theory as they are related to human rights in Asia or the Americas, and/or projects that concentrate on particular legal or social problems related to human rights and endemic to societies in either region. Papers dealing with issues of Armed conflicts and International law are particularly encouraged.

Primary Keyword: War, and Armed Conflict.

Secondary Keyword: International Law, International Organizations, Regional Institutions, Nonstate Actors, and International Politics.

\section{$\underline{\text { Papers }}$}

\section{"Foreign Agents" in an Interconnected World: The Politicization of FARA}

The Foreign Agents Registration Act (FARA) is a notoriously sweeping and generally underenforced public disclosure statute. Enacted in 1938, FARA was used during World War II to 
target Fascist and Communist propaganda, but by the 1960s its enforcement had shifted to lobbyists for foreign governments. After the 2016 U.S. Presidential election, FARA has gained favor as a potential tool to regulate a range of foreign influences on U.S. politics, including foreign lobbying, propaganda, and election interference. This article argues that a shift in the use of FARA creates substantial risk that it will be used in a politicized manner, particularly against non-profits and media organizations. In the past decade "foreign agent" laws in other countries - often justified on FARA - have been used to undermine dissent. FARA's broad and unclear provisions make it susceptible to being similarly "weaponized", or used to threaten certain voices with the stigma and burden of registering as a "foreign agent". This article undertakes a detailed analysis of FARA to show how it can require a wide range of actors to register. It then examines three case studies to show how FARA's enforcement has both historically and recently been politicized, and explain why FARA's increased use would likely aggravate this problem. The article ends by weighing the merits of using FARA to address different types of foreign influence and argues that successful FARA reform requires acknowledging its full costs, clarifying its purpose, and better targeting its language.

Presenter: Nick Robinson - International Center for Not-for-Profit Law

\section{International Law and Local Public Policy: the role of international cooperation for the enforcement of human rights in South America}

This research investigates how South American transnational networks create law and legal norms, and in the process, shape national and international social and political institutions to enforce human rights. To perform this study, we had produced a systematic, grounded and objective reflection about the mechanisms of international cooperation effectively put into practice between Brazil and all South American countries and inquiry if there is a link between these cooperation regimes and the effective construction of local public policies. Methodologically, the research conducts an extensive and detailed documentary analyze and empirical exploration combining quantitative (identification and classification of treaties, topics and institutions) and qualitative analyzes (case studies and international comparison). This combination of methods allows a broader interpretation of the actors and networks' 
demand to create international norms that are able to improve transnational cooperation (input), and to inquiry if these treaties product domestic public policy (output). The research was developed in three stages. The first was an extensive documentary examination, which resulted in a database of all treaties in force between Brazil and all South American counties raleted to health, education and enviroment. The second stage was the verification of which initiatives were subject to appropriate legal treatment in the Brazilian legal system institutional structure, regulatory framework and Brazilian jurisprudence. In the third stage, two regimes will be chosen for qualitative analysis, and we want to examine the role of actors and mechanisms in the creation of transnational law, norms and legal orders and their impact on domestic law and institutions.

Presenter:Ademar Pozzatti Junior - Universidade Federal de Santa Catarina

\section{The legal aspects of the concepts of preventive self-defense and preemptive self-defense and the use of drones in International Law}

This work intends to analyze the discussions that involve the use of new technologies as paradigm change promoters in the international field of armed conflict, correlating their use with the legal aspects of the concepts of preventive self-defense (anticipated) and preemptive self-defense (immediate). Such concepts have their own definitions within international law. Preemptive actions refer to those that are carried out in a context of defense against an immediate threat that is already occurring. It is the threat here and now. On the other hand in the prevention, or preventive action, unlike the preemptive action, the nature of the threat is more distant, as much in the time as in the space. Thus, the ethical barrier to the preventive use of force is greater than for preemptive use. However, from the Bush administration and the creation of the NSS 2002 (National Secutiry Strategy 2002) discussions around these concepts have become a constant. At the heart of this document and in the ensuing debates, the two concepts were used in an obscure and ambiguous way, exchanging themselves in the discourses, creating a "semantic fog" that facilitates and justifies actions that go beyond the current international legal order. In this context, drones have been used in an increasingly constant way as agents promoting strategic actions aimed at reaching selected targets, marked 
as threatening state security. In this scenario, the self-defense is put as a legal justification for carrying out "preventive" attacks, either on the premises and infrastructure within the territory of sovereign states or against isolated individuals within those states, in a tactical action called targed killing. Methodologically the work uses research in bibliographical sources, primary and secondary, analyzing the texts of such documents with the focus on discourse analysis, especially to that proposed by Patrick Charaudeau.

Presenter: Ronaldo Lucas da Silva - Universidade Estácio de Sá

\section{Civilian victims of targeted killings by paramilitary groups in Afghanistan}

The objective of the paper is to explore the impact of targeted killings by paramilitary groups on the civilian population in Afghanistan. The paper is based on extensive fieldwork in Afghanistan, carried out between 2008 and 2017, and data gathered from the relevant literature. The paper is divided into four sections. The first section provides an overview of Afghan paramilitary groups and the support provided to them by the U.S.-led military coalition in Afghanistan. The second section explores the too-broad criteria used by progovernment militias for determining what they believed were legitimate military targets. The section analyzes how the militias regularly targeted civilians perceived to be linked to the insurgency (e.g., family members and relatives of insurgents, civilians suspected of providing assistance to insurgents, and civilians living in areas from where insurgent attacks were launched). The third section of the paper examines how militia members targeted civilians who, despite not being linked to the insurgency, refused to submit themselves to the authority of the militias (e.g., political and religious figures objecting the militias' activities, civilians refusing to pay illegal taxation imposed by the militias, and civilians involved in personal feuds with militia members). The last section explores how the too-broad target selection criteria ignored the standard definitions of legitimate military targets in non-international armed conflicts, and, consequently, led to attacks that violated the principle of distinction between combatants and civilians, a key principle of international humanitarian law.

Presenter: Vasja Badalič - Institute of Criminology at the Faculty of Law 


\section{Two Calls from Kunduz: Exploring the Space between Accidents and War Crimes in Armed Conflict}

"This was not just an attack on our hospital - it was an attack on the Geneva Conventions." This conclusion was offered by the international humanitarian organization Médecins Sans Frontières days after the U.S. military attacked a trauma center operated by MSF in Kunduz, Afghanistan in October 2015. "Under the clear presumption that a war crime has been committed," the organization demanded that the U.S. permit an investigation by an independent fact-finding commission. In the end, the U.S. military performed its own internal investigation, rejected the war crime characterization, and refrained from initiating criminal prosecution for any person involved in the attack. This incident is but one example of the discord that often follows such purported accidents in armed conflict. The tension between competing characterizations - tragic accident and inexcusable war crime - often remains unresolved. The disconnect between public expectations and government practice can erode public support and threaten the legitimacy of present and future military operations. The incongruence between perspectives is largely attributable to disparate concepts of the term "war crime". Official narratives typically adopt a doctrinal legal approach that is incompatible with popular and scholarly perspectives that often employ a more colloquial approach to the term. This paper examines two separate incidents of civilian casualties in Kunduz, Afghanistan to explore the conflict between competing narratives. By adhering to a strictly doctrinal approach, official narratives fail to account for the ways in which incidents of civilian casualties are experienced in society. Lawyers play an important role in shaping doctrinal narratives, but respecting the dignity of social narratives demands a more holistic approach. This paper explores the space between accidents and war crimes to consider whether competing narratives can be reconciled and the persistent discord resolved.

Presenter: Brian Cox - Queen's Law. 


\title{
Session XVIII:
}

\section{Current legal issues in Asia and Americas II}

\author{
Abstract $N^{\circ}: \mathbf{2 9 3 6}$ \\ CRN: 01 \\ Session Organizer: Ronaldo Lucas da Silva - Universidade Estácio de Sá. \\ Chair: Fernanda Duarte - UNESA e INCT/InEAC/PROPPI/UFF \\ Discussant: Rafael Mario Iorio Filho - Universidade Estácio de Sá e INCT-InEAC
}

\section{Conclusions:}

This session covers legal and social issues in Asia and the Americas related to the human rights debate. Examples might include discussions of contemporary political or legal challenges faced by governments, social groups or individuals, analyses of emerging trends in legal theory as they are related to human rights in Asia or the Americas, and/or projects that concentrate on particular legal or social problems related to human rights and endemic to societies in either region.

Primary Keyword: Human Rights, International Human Rights

Secondary Keyword: Access to Justice

\section{$\underline{\text { Papers }}$}

Evicting the elderly: magistrates face unjust procedural and social policies

Evicting the elderly: magistrates face unjust procedural and social policies This communication proposal aims to present the results of research aimed at documenting and analyzing the causes and consequences of housing evictions for the elderly. Conducted in 
partnership with the Montreal Legal Clinic (CJI), this research is based on the study of the life course of thirty people over 60, expelled from their homes in the last five years. More specifically, by tracing the judicial process, i.e. the causes of the eviction (Part I), the steps taken during the procedure, the judgment (Part II), the social, health and legal consequences of the eviction (Part III), this communication proposal wishes to document an underdocumented problem. In fact, in the field of social sciences (Desmond, 2012, 2015) as in the legal field, the available works have highlighted the racist and sexist nature of the eviction procedures (Franzese, 2018, Greenberg and al., 2016). The « social relations of ages » remain for their part largely in the blind spot of the analysis, both as regards of the eviction itself and in terms of access to justice. In a context of an ageing population, where Western states are questioning pension schemes even though people over 60, particularly older and racialized women, are among the poorest social categories in the society (Grenier et al., 2016, Sussman et al., 2016) we will defend the hypothesis that the eviction of the elderly highlight both, the indignity of the current eviction proceedings and the indignity of social policy.

Presenter: Martin Gallié - Université du Québec à Montréal

\section{Systemic Law as a Tool for Peaceful Conflicts}

Systemic Law is inserted and recognized in the culture of pacification. In analysis is a new approach to the law that has shelter in the Brazilian legal system through the preamble of the Greater Law, founded on social harmony and committed to the peaceful settlement of controversies, proposing a differentiated view of the conflict for peaceful and effective solutions, using of Hellinger's philosophy. These techniques aim to meet a new education proposal and its need to move towards a human rights culture to promote greater dignity for all. It provides the judge with a differentiated view, without judgments, of transformation of human destinies, providing the effectiveness of the judicial service, with a systemic view of the Judiciary and all those involved in the process. Phenomenology has the importance of bringing out the essentials. The solution is embedded in the problem itself. There is something beyond polarity. It is necessary to understand that each person has its own dynamics, and each dynamics must be analyzed in an individualized way. To look at the conflict with a broader 
glance, to see the process not as roles, but as an exposition of aspirations, feelings, weaknesses, lives that need help and a look of respect, attention, altruism and otherness. The objectives are oriented towards the identification of the importance of systemic law, as well as the legal and conceptual bases regarding the relevance of its application to the peaceful solution of conflicts in contemporary society.

Presenter: Ana Cristina Augusto Pinheiro - Universidade Estácio de Sá

\section{Human Dignity in Brazilian procedural law: Courts' legitimacy through Human Rights}

As perhaps the most important principle over which the Brazilian Democratic State was built, human dignity plays a decisive role in many if not all aspects of the country's organization. Assured in the Constitution as a fundamental principle, defining the way public power must act towards its citizens, it can be understood as the foundation of the State's rulings legitimacy. Ensuring human dignity is respected in civil procedure, however, represents a great challenge, when taking into account Brazil is a continent sized country with 100 million people litigating in courts. If indeed Brazilians have easy and cheap access to justice, being able to submit their issues to the judiciary in a relative simple way, problems such as slow procedures and contradictory rulings do come forth, arising the question: to which extent the mere fact of filing a lawsuit represents true access to justice? Are the right to be heard and the right to have a ruling in reasonable time important in a civil procedure system? Building an efficient civil procedure system is directly linked to respecting human dignity, which manifests itself as the intrinsic value the individual has within the procedural system. In that sense, this paper analyzes the binding decisions building mechanisms and their forms of contradictory, created within the 2015 Brazilian Civil Procedure Code, in order to verify their effectiveness in ensuring this principle. Using the statistics made available by the CNJ (the National Counsel of Justice), combined with professor's Câmara (2018) concept of Due Constitutional Process, this paper concludes the tools available can be effective not only guaranteeing a reasonable procedure time span, but also assuring all parties' arguments will be taken into account by courts when building a binding ruling. 
Presenter: Nilo Rafael Baptista de Mello - Universidade Estácio de Sá

\section{Human Dignity under modern Japanese constitutional law}

Although Japan's constitution makes no clear mention to the concept of 'human dignity' (the closest reference to such an idea can be found in the words by Article 13: "All of the people shall be respected as individuals) it is widely accepted among modern scholars that the protection of human dignity is the cornerstone of the Japanese constitutional system. Thus respect for human dignity is generally constructed as Japan's constitutional commitment to the protection for fundamental human rights, even those whose protection is not explicitly covered by any particular constitutional provision, such as rights toward individual autonomy and rights to privacy and private life. However, it has been pointed out that the construction of human dignity showed by Japanese courts in general, and Japan's Supreme Court in particular, somehow lags behind the modern understanding of human dignity, particularly when assessed by international human rights law standards. This paper will explore the significance of human dignity within Japan's postwar constitutional development. Furthermore, as a methodological premise, these developments will be examined through the prism of cultural analysis in order to put them in the context of a society that, traditionally, has been known for its group orientation.

Presenter: Luis Pedriza - Dokkyo University

\section{Crimes and Constitutions: The Legacy of Democracy's Institutionalization by Elites in South Korea and Chile}

South Korea and Chile are usually considered as examples of successful democratization. Both countries have more in common than the timing of their transition in the late 1980s, being part of the "third wave" that swept various continents' dictatorships. The modalities through which democracy was institutionalized in South Korea and Chile also display intriguing similarities. In addition to representing two instances of "pacted," as opposed to 
"ruptured," transition, South Korea and Chile belong to a subclass of cases that has not yet received proper scholarly attention. These cases, which also include Hungary, Taiwan, and Indonesia, are characterized by their enactment of regime change through the amendment, rather than replacement, of the authoritarian constitution. This paper first examines the changes that resulted (or not) from this process, conducting a close analysis of the South Korean and Chilean constitutions before and after their revisions. What pre-transitional provisions were retained and which were removed or altered? How did the two texts signal their commitment to human rights norms without changing their overall frameworks? The analysis then explores the legacy of democracy's institutionalization by elites in the realm of transitional justice, reconstituting the legal and political path that was followed in South Korea and Chile to confront (or not) the two countries' violent pasts. Given the members of the old regime's role as "founding fathers" of the new order, what measures were taken to shield them from being punished for the crimes committed before the change of regime? Why were these measures sometimes adopted preventively (under the form of amnesty laws and agreements to prevent prosecutions) and at other times reactively (under the form of pardons and sentence commutations)? This comparison of two transitions by amendment will contribute to the 2019 conference theme by addressing the issue of "dignity and the unwritten code of democracy."

Presenter: Justine Guichard - George Washington University

Presenting Co-Author: Florence Larocque - Université de Montréal

\section{The Coalition Hyper-presidentialism System and the Judicialization of Politics in Brazil}

This paper aims to explore the relationship between three distinctive phenomena: a coalition presidentialism political system that presents itself as the current political arrangement between the legislative and the executive branches in Brazil, the judicialization of politics and its growth in the Brazilian political/juridical reality and the hyper-presidentialism phenomenon, common to all Latin-American countries. The theoretical framework used is primarily based on Sérgio Abraches work "Presidencialismo de coalizão: Raízes e evolução do modelo político brasileiro" and Roberto Gargarella's book "La sala de máquinas de la 
Constitución. Dos siglos de constitucionalismo en América Latina". Methodologically, this paper focus in an analytical-descriptive approach combined with statistical references and an empirical method. The partial conclusions that can be inferred from this research project validates the main hypothesis, indicating a strong correlation between the Coalition Hyperpresidentialism system and the judicialization of politics in Brazil, as systems that continuously feeds each other.

Presenter: Leonardo Fernandes de Sá - Universidade Federal do Rio de Janeiro.

Presenting Co-Author(s): Guilherme Niskier - Veiga de Almeida University

Isabella Rocha - UNIRIO 


\section{Submissions rountable}

\section{Session XIX:}

\section{Comparative Study of the Theoretical Foundations of Judicial Deference}

\section{Submission Number: 1298}

\section{CRN: 01}

Session Organizer: Fernanda Duarte - UNESA e INCT/InEAC/PROPPI/UFF

Chair: Ricardo Perlingeiro - Estácio de Sá University; Fluminense Federal University

Participant(s):

Anne Richardson-Oakes - Birmingham City University

David Ritchie - Mercer University

Fernanda Duarte - UNESA e INCT/InEAC/PROPPI/UFF

Friso Jansen - Birmingham City University

Ilaria Di Gioia - Birmingham City University

Rafael Mario Iorio Filho - Universidade Estácio de Sá e INCT-InEAC

\section{Description:}

The power balance within the state has always been a challenge to modern western democracies. This challenge is even more acute when we consider the relations between the judicial branch and the executive branch, in particular considering judicial review and deference. This roundtable intends (1) to identify parallels and contrasts between the theoretical approaches to judicial deference to administrative decisions (front-line decisions and adjudication decisions) in the United Kingdom, USA and Brazil; (2) to explain the variety 
of judicial arguments in favor of deference and to correlate them with the corresponding constitutional theories; (3) to contribute to the understanding of the theoretical foundations of judicial deference, which may be used for possible recommendations for the use of such deference.

Primary Keyword: Legal Culture, Legal Consciousness, Comparative Legal Cultures.

Secondary Keyword: Access to Justice. 


\section{$\underline{\text { Session } X X}$ :}

\section{Themes on Comparative and International Procedural law}

\section{Submission Number: 1263}

\section{CRN: 01}

Session Organizer: Fernanda Duarte - UNESA e INCT/InEAC/PROPPI/UFF.

Chair: Aluisio Mendes - UNESA /UERJ

\section{Participant(s):}

Ines da Trindade Chaves de Melo - UNESA

Amanda de Lima Vieira - UNESA

Cesar Felipe Cury - UNESA/TJRJ

Guilherme Calmon - UNESA /UERJ

Larissa Pochmann da Silva - UCAM

Maria Carolina Amorim - UNESA

Ubirajara da Fonseca Neto - UNESA

\section{Description:}

This roundtable counts with Postdoctoral researchers, Doctoral students and Masters in Law, all supervised by Profs Aluisio Mendes and Guilherme Calmon at UNESA/Brazil. It deals with matters as: a) different dimensions of precedents in Brazil and in the US; b) the new functions of the Judiciary in terms of establishing legal interpretation in a concentrated way in Common and Civil Law countries; c) current and controversial issues in the Hague Convention on the Civil Aspects of International Child Abduction; d) collective procedural law: innovations and perspectives; e) ethical probity in public administration in Brazil and in the US; f) online dispute resolution (ODR) and access to the legal system in Brazil and in the US; g) case management in national and international courts. 
Primary Keyword: Access to Justice.

Secondary Keyword: Civil Justice, Adjudication, and Dispute Resolution. 


\section{Session XXI:}

\section{Human Rights, Education and Democracy}

\section{Submission Number: 2817}

\section{CRN: 01}

Session Organizer: Rafael Mario Iorio Filho - Universidade Estácio de Sá e INCT-InEAC

Chair: César Augusto Ribeiro Nunes - PPGD-Universidade Estácio de Sá - UNESA/RJ

\section{Participant(s):}

Flávia Piovesan - Comissão Interamerica de Direitos Humanos

Leopoldo Soares - Centro Universitário Estácio de Ribeirão Preto

Alexandre Sanches Cunha - Complexo de Ensino Renato Saraiva (CERS)

Carla de Marcelino Gomes - Ius Gentium Conimbrigae (IGC/Human Rights Centre Coimbra, Portugal)

Catarina Gomes - Ius Gentium Conimbrigae (IGC/Human Rights Centre - Coimbra, Portugal) Ana Filipa Neves - Ius Gentium Conimbrigae (IGC/Human Rights Centre - Coimbra, Portugal)

Rita Perdigão - Ius Gentium Conimbrigae (IGC/Human Rights Centre - Coimbra, Portugal)

\section{Description:}

This roundtable is designed to analyze and debate the theoretical frameworks and practical assumptions that enable the effective guarantee of the right to education in the construction of a modern Theory of Human Rights. In addition, the roundtable aims to discuss specific themes of research in the area of Human Rights that can contribute to the affirmation, in contemporary societies, of the values, attitudes and social practices that express the culture of Human Rights based on the defense of the dignity of more vulnerable social groups. Finally, it will give us the opportunity to discuss the socio-philosophical and legal parameters for the 
formation of a new paradigm of Human Rights, through a human rights-based approach to education.

Primary Keyword: Human Rights, International Human Rights.

Secondary Keyword: Citizenship (social as well as legal). 